\title{
How Many Faces Does the Plant U-Box E3 Ligase Have?
}

\author{
Xinguo Mao ${ }^{1, *,+}{ }^{+}$, Chunmei Yu ${ }^{1,+}{ }^{\dagger}$,ong $\mathrm{Li}^{1}{ }^{1}$, Min Wang ${ }^{1}$, Lili Yang ${ }^{1}$, Yining Zhang ${ }^{1}$, Yanfei Zhang ${ }^{1}$, \\ Jingyi Wang ${ }^{1}{ }^{\mathbb{D}}$, Chaonan $\mathrm{Li}^{1}{ }^{1}$, Matthew Paul Reynolds ${ }^{2, *}$ and Ruilian Jing ${ }^{1}{ }^{\mathbb{D}}$
}

1 The National Key Facility for Crop Gene Resources and Genetic Improvement, Institute of Crop Sciences, Chinese Academy of Agricultural Sciences, Beijing 100081, China; yuchunmei272@163.com (C.Y.); lilong01@caas.cn (L.L.); wanming0127@163.com (M.W.); 19956730179@163.com (L.Y.); zyn18845111029@163.com (Y.Z.); yfz15838298834@163.com (Y.Z.); wangjingyi@caas.cn (J.W.); lichaonan@caas.cn (C.L.); jingruilian@caas.cn (R.J.)

2 International Maize and Wheat Improvement Center, Texcoco 56237, Mexico

* Correspondence: maoxinguo@caas.cn (X.M.); m.reynolds@cgiar.org (M.P.R.)

$\dagger$ The authors contribute equally to this work.

check for updates

Citation: Mao, X.; Yu, C.; Li, L.; Wang, M.; Yang, L.; Zhang, Y.; Zhang, Y.; Wang, J.; Li, C.; Reynolds, M.P.; et al. How Many Faces Does the Plant U-Box E3 Ligase Have? Int. J. Mol. Sci. 2022, 23, 2285. https:// doi.org/10.3390/ijms23042285

Academic Editor: Karen Skriver

Received: 29 December 2021

Accepted: 8 February 2022

Published: 18 February 2022

Publisher's Note: MDPI stays neutral with regard to jurisdictional claims in published maps and institutional affiliations.

Copyright: (C) 2022 by the authors. Licensee MDPI, Basel, Switzerland. This article is an open access article distributed under the terms and conditions of the Creative Commons Attribution (CC BY) license (https:// creativecommons.org/licenses/by/ $4.0 /)$.

\begin{abstract}
Ubiquitination is a major type of post-translational modification of proteins in eukaryotes The plant U-Box (PUB) E3 ligase is the smallest family in the E3 ligase superfamily, but plays a variety of essential roles in plant growth, development and response to diverse environmental stresses. Hence, PUBs are potential gene resources for developing climate-resilient crops. However, there is a lack of review of the latest advances to fully understand the powerful gene family. To bridge the gap and facilitate its use in future crop breeding, we comprehensively summarize the recent progress of the PUB family, including gene evolution, classification, biological functions, and multifarious regulatory mechanisms in plants.
\end{abstract}

Keywords: abiotic stress; biotic stress; development; E3 ubiqutin ligase; plant U-box protein; ubiquitination

\section{Introduction}

Ubiquitination is a major type of post-translational modification of proteins, occurring widely in eukaryotic cells, and plays pivotal roles in regulating the synthesis and degradation of proteins in plant growth, development and responses to environmental signals. Ubiquitin is a stable, highly conserved, and universally expressed protein. It covalently attaches to a lysine residue of target proteins, and therefore alters their stability, activity, trafficking and cellular localization. The ubiquitination system consists of several enzymes that act in concert. A ubiquitin-activating enzyme 1 (E1) catalyzes the formation of a thioester bond between E1 and ubiquitin in the presence of ATP and then delivers the activated ubiquitin to a ubiquitin-conjugating enzyme (E2); subsequently E2 transfers the ubiquitin to a ubiquitin-protein ligase (E3). E3 ligase plays a central role in determining the specificity of the ubiquitination system by candidate protein selection [1]. Eventually, the ubiquitin-labeled protein will be degraded by the ubiquitin 26S-proteasome system (UPS).

Given myriad downstream substrates, E3s are the most diverse components in the ubiquitination pathway [2]. For instance, more than 1300 E3 genes are identified in the Arabidopsis genome [3]. Based on subunit compositions and regulatory mechanisms, the E3s are divided into four main families, including Homologous to E6-associated protein Carboxyl Terminus (HECT), U-box, Really Interesting New Gene (RING) and Cullin-RING Ligase (CRL) [4]. Among them, the U-box type E3 ligase is the smallest family.

\section{Classification and Evolutionary Characteristics of U-Box Proteins \\ 2.1. Structural Characteristics of the Conserved U-Box Domains}

The U-box is a more recently identified protein domain with E3 ligase activity, which was first found in ubiquitin fusion degradation protein 2 (UFD2) in yeast $[5,6]$. The 
U-box domain is a modified RING-finger domain, lacking the zinc-chelating cysteine and histidine residues of RING-finger domains [7]. The conserved zinc-binding sites (cysteine and histidine residues) supporting the cross-brace arrangement in RING-finger domains are replaced by hydrogen-bonding networks in the U-box. The U-box scaffold is stabilized by a system of salt bridges and hydrogen bonds. The charged and polar residues participating in the network of bonds are more conserved than those in classic RING fingers, revealing their irreplaceable role in maintaining the stability of U-box [7]. A conservative $\mathrm{Val} \rightarrow$ Ile substitution disrupts structural integrity of the U-box and leads to pre-mRNA splicing defects of Prp19p [8]. Moreover, both U-box and RING fingers contain a conserved interaction surface. Mutagenesis of residues at the interface does not perturb the structure of U-box, while abrogating the function of Prp19p in vivo [8]. In Arabidopsis, identical amino acids are present in the corresponding conservative positions in the U-box domains of AtPUB14 and many other plant U-box proteins [9].

\subsection{Evolutionary Characteristics of PUBs in the Viridiplantae}

The number of U-box proteins varies greatly in fungi, animals and plants. There are only two U-box genes, i.e., UFD2 and PRP19, in the yeast genome [6]. In humans, eight U-box genes are found, including UBE4A, UBE4B, UIP5, PRP19, CHIP, CYC4, WDSUB and Act1 [10]. Intriguingly, six of the seven main U-box genes of humans (UBE4A, UBE4B, UIP5, PRP19, CHIP and CYC4) are present in the ancestor of all current metazoans, and WDSUB is found in placozoans, cnidarians and bilaterians, revealing that the U-box genes are evolutionarily conserved and occurred before the emergence of animals [10].

In Viridiplantae, including green algae, the plant U-box (PUB) E3 ligase gene family has expanded remarkably compared to those of fungi and animals. For instance, there are 30, 64, 67, 62 and 77 members in the genomes of Chlamydomonas reinhardtii [11], Arabidopsis [12], barley [13], tomato [14] and rice [2], respectively. For polyploidy plant species, the gene number is even greater because of the occurrence of whole genome duplication [15-17]. For instance, over 200 PUB genes are present in the genome of tetraploid cotton and hexaploid wheat $[15,16]$. Phylogenetic and gene structure data have shown that the PUB gene families have experienced various duplication events. In Chlamydomonas, one gene duplication event is found [11]. In barley (Hordeum vulgare L.), two or more HvPUB genes are arranged tandemly or closely clustered together on the chromosomes. For instance, $H v P U B 11 / 12$ and HvPUB58/59 are in tandem and have $100 \%$ sequence identity, indicating that gene duplications occurred recently. However, some gene pairs, such as HvPUB6/43/52, HvPUB13/25, HvPUB15/16 and HvPUB28/29, are different, hinting that the duplication events might be occurred at earlier time [13]. In Gossypium raimondii, 15 segmental duplications and three tandem duplications are found in the homologous gene pairs, and 25 segmental duplications and two tandem duplications are identified in G. arboretum [16]. In tetraploid cotton G. hirsutum, more gene pairs are identified than the sum of its genome donors, suggesting that the duplication events happened postpolyploidization [16]. In wheat, 18 pairs of duplicated U-box E3 genes are identified, and six pairs show duplication events in the equal chromosome on $4 \mathrm{~A}, 5 \mathrm{~A}, 5 \mathrm{~B}$, and $6 \mathrm{~B}, 12$ pairs of segmental duplication events are detected between different chromosomes, such as between chromosomes $4 \mathrm{~A}$ and $7 \mathrm{~A} / 7 \mathrm{D}, 4 \mathrm{~B} / 4 \mathrm{D}$ and $5 \mathrm{~A}$, and $5 \mathrm{~A} / 5 \mathrm{~B} / 5 \mathrm{D}$ and $6 \mathrm{~A}$ [15]. It is hypothesized that the wide expansion of PUB genes is an essential strategy for sessile plants to adapt the environmental challenges [18], very much in tune with their functions in responses to biotic and abiotic stresses.

\subsection{Classifications of PUBs in Various Plant Species}

To characterize U-box containing proteins, the protein family is further divided into several groups based on the presence or absence of distinctive functional domains, such as ARM (Armadilo repeat), CYC4 (cyclophilin), GKL motif, UFD2, U-box, WD40, TRR (tetratrico-peptide repeat), and protein kinase domain $[2,13]$. The PUBs are divided into three groups in Chlamydomonas; five in pear; six in banana; seven in wheat, peach and 
cabbage; eight in Arabidopsis, rice, barley and soybean (Table 1). However, there is no one-to-one correspondence between the classifications from various plant species, because of the huge differences in gene number and domain/motif types, as well as the classification criteria employed by researchers. Moreover, the emergence of new PUB proteins further complicates the classifications $[15,16]$.

Table 1. Comparisons of gene number and classifications of the U-box E3 ubiquitin ligases in various species.

\begin{tabular}{|c|c|c|c|}
\hline Species & Gene Number & Classifications & References \\
\hline Saccharomyces cerevisiae (Yeast) & 2 & 2 & [10] \\
\hline Homo sapiens (Human) & 8 & 7 & [10] \\
\hline Chlamydomonas reinhardtii & 30 & 3 & [11] \\
\hline Arabidopsis thaliana & 64 & 8 & [2] \\
\hline Oryza sativa (Rice) & 77 & 8 & [2] \\
\hline Horderm vulgare (Barley) & 67 & 8 & [13] \\
\hline $\begin{array}{l}\text { Triticum turgidum ssp. Dicoccoides } \\
\text { (Emmer wheat) }\end{array}$ & 82 & 7 & [19] \\
\hline Triticum aestivum (Bread wheat) & 213 & 7 & [15] \\
\hline Glycine max (Soybean) & 125 & 8 & [17] \\
\hline Brassica oleracea (Cabbage) & 99 & 7 & [20] \\
\hline $\begin{array}{c}\text { Brassica rapa ssp. Pekinesis } \\
\text { (Chinese cabbage) }\end{array}$ & 101 & 10 & [21] \\
\hline Lycopersicon esculentum (Tomato) & 62 & 4 & [14] \\
\hline Musa nana (Banana) & 91 & 6 & [20] \\
\hline Prunus persica (Peach) & 54 & 7 & [22] \\
\hline Pyrus bretschneideri (Pear) & 62 & 5 & [23] \\
\hline Gossypium arboretum (Diploid cotton) & 96 & 11 & [16] \\
\hline G. barbadense (Tetraploid cotton) & 208 & 14 & [16] \\
\hline G. hirsutum (Tetraploid cotton) & 185 & 17 & [16] \\
\hline G. raimondii (Diploid cotton) & 93 & 11 & [16] \\
\hline
\end{tabular}

\section{PUBs Are Involved in the Regulation of Gene Expression in Different Ways}

\subsection{PUBs Control the miRNA Biogenesis}

MicroRNAs (miRNAs) are endogenous small non-coding RNAs controlling gene expression by guiding the cleavage or translational inhibition of complementary mRNAs. Compelling evidence shows that miRNA participates in various biological processes in plants. The biogenesis of miRNA in plants requires numerous proteins, and the processing complex consists of the core components DICER-LIKE 1 (DCL1), SERRATE (SE) and HYPONASTIC LEAVES (HYL1). Among proteins associated with the DCL1 complex, CDC5 and PRL1 are two core subunits of the conserved MOS4-associated complex (MAC) [24]. MAC contains three core subunits, MAC3A, MAC3B, and MOS4, and more than 13 accessory proteins with diversified functions. MAC3A and MAC3B are conserved U-box-containing proteins in eukaryotes. Deficiency in MAC impairs plant immunity and development [24]. Mutation of both MAC3A and MAC3B leads to the reduction of miRNA and primary miRNA transcripts (pri-miRNAs) levels, and causes elevated transcripts of miRNA targets in Arabidopsis. In vivo evidence has shown that MAC3A associates with pri-miRNAs, indicating that MAC3A and MAC3B may stabilize pri-miRNAs. Furthermore, MAC3A and MAC3B interact with the DCL1 complex that catalyzes miRNA maturation, promote DCL1 activity, and are required for the D-body localization of HYL1 [25]. MAC 
functions as a complex to control miRNA levels through modulating pri-miRNA transcription, processing and stability. However, MAC3A and MAC3B act redundantly in miRNA biogenesis [25].

\subsection{PUBs Are Involved in the Signal Transductions of Various Phytohormones}

Compelling data have established that PUBs are involved in the regulating gene expression via different phytohormone signaling pathways. Brassinosteroid-Insensitive 1 (BRI1) is a leucine-rich repeat receptor-like kinase that functions as the cell surface receptor for brassinosteroids (BRs), transducing the extracellular BR signal into the nucleus. BR perception promotes BRI1 ubiquitination by AtPUB12 and AtPUB13, and association with AtPUB12 and AtPUB13 through phosphorylation at serine 344 residue. Loss of AtPUB12 and AtPUB13 results in reduced BRI1 ubiquitination and internalization accompanied with a prolonged BRI1 plasma membrane-residence time, suggesting that the ubiquitination of BRI1 by AtPUB12/13 is a key step in BRI1 endocytosis [26].

In rice, Taihu Dwarf 1 (TUD1) encodes a functional PUB E3 ubiquitin ligase. D1 encodes the $\alpha$ subunit of heterotrimeric G-protein RGA1, and plays important roles in many signal transduction pathways. Genetic, phenotypic, and physiological data have shown that OsTUD1 is epistatic to OsD1/RGA1 and the ostud1 mutant is less sensitive to BR treatment. Histological observations show that the dwarf phenotype of ostud1 is mainly due to decreased cell proliferation and disorganized cell files in aerial organs. Protein interaction assays show that OsTUD1 directly interacts with OsD1/RGA1, demonstrating that OsTUD1 and OsD1 act together, therefore influencing plant growth and development via an OsD1/RGA1-mediated BR-signaling pathway in rice [27].

PHOR1 (photoperiod-responsive 1), which encodes an ARM repeat-containing PUB protein in potato (Solanum. tuberosum ssp. andigena), is required in the process of tuberization under short-day conditions. Antisense inhibition of PHOR1 produces a semi-dwarf phenotype similar to that of gibberellic acid (GA)-deficient plants, and the antisense lines show reduced GA responsiveness combined with a higher endogenous GA content than the WT plants. Conversely, transgenic lines overexpressing PHOR1 display an enhanced response to GA. Application of exogenous GA induces a rapid migration of PHOR1-GFP protein to the nucleus. Hence, PHOR1 is a key component of GA signaling pathway $[28,29]$.

MYC2 is an important regulator for jasmonic acid (JA) signaling. AtPUB10 is an ARM repeat-containing PUB. Both MYC2 and AtPUB10 are nucleus localized. AtPUB10 interacts with and ubiquitinates MYC2 jointly with E2 enzyme UBC8. MYC2 is unstable in WT plants, whereas its stability is enhanced in atpub10 mutant, suggesting the destabilization by AtPUB10 [30]. Furthermore, the half-life of MYC2 is shortened in AtPUB10 plants, but prolonged in atpub10 mutant and the dominant-negative AtPUB10 (C249A) mutant. Root growth of atpub10 seedlings phenocopies MYC2-overexpressing seedlings and is hypersensitive to methyl jasmonate, whereas AtPUB10 transgenic plants and jin1-9 (myc2) seedlings are hyposensitive JA. In addition, the root phenotype conferred by MYC2 overexpression in double transgenic plants is reversed or enhanced by induced expression of AtPUB10 or AtPUB10 (C249A), respectively. In short, AtPUB10 participates in the JA signaling pathway by targeting MYC2 for degradation [30].

The S-domain receptor kinases (SRKs) are positive regulators of self-incompatibility (SI) response, and capable of phosphorylating the ARM repeat domains of PUBs in vitro. ARK1 (SD1-7) is a member of SRKs in Arabidopsis. AtPUB9 is a U-box protein with ARM domains. Both ARK1 and AtPUB9 display a predominant localization in the nucleus, a steady-state localization pattern [31]. Interestingly, AtPUB9 exhibits redistribution to the plasma membrane of tobacco BY-2 cells when either treated with ABA or co-expression with the active kinase domain of ARK1. As well, T-DNA insertion mutants for ARK1 and AtPUB9 lines show altered sensitivity to ABA during seed germination. Genetic assays reveal that ARK1 and AtPUB9 most likely functions in a linear fashion, and act at or upstream of $\mathrm{ABI} 3$, demonstrating their potential involvements in ABA responses [31]. 
Additionally, PUBs are also implicated in various phytohormone-mediated pathways of fruit development and ripening (see the section of fruit ripening).

\section{PUBs Are Omnipotent Players in the Responses to Various Abiotic Stress}

Expression profile is the most direct indicator of involvement of a gene in a specific biological process. Fueled by the development of genome sequencing and the popularity of transcriptome sequencing, many PUB genes are identified as participants in the response to abiotic stress. For instance, a total of 118 PUB genes show drought- and heat-stress-specific expression patterns in wheat [15], 60 genes are induced by drought/salt/low temperature in banana [20], 11 out of $67 \mathrm{HvPUB}$ genes are at least two-fold induced by drought in barley seedlings [13], supporting the extensive involvements of PUBs in abiotic stress responses.

\subsection{PUBs Are Pivotal Regulators in the Response to Drought Stresses}

Drought stress is the major environmental limitation for plant growth and development. Many PUBs are involved in the response to drought stress and serve as positive or negative regulators in the processes. In Arabidopsis, several PUBs play negative roles in response to drought stress (Table 2). For instance, AtPUB11 negatively modulates drought tolerance by degrading ABA and drought stress responsive receptor-like protein kinases, Leucine-Rich Repeat Protein 1 (LRR1) and kinase 7 (KIN7). Mutation of AtPUB11 leads to a phenotype of drought tolerance, while $\operatorname{rr} 1$ and $k i n 7$ mutants are more sensitive to drought stress than WT [32]. AtPUB18 and AtPUB19 are homologous PUB E3 ligases. The atpub18-2atpub19-3 double mutant displays more sensitivity to ABA and enhanced drought tolerance than each single mutant plants and WT [33]. AtPUB22 and AtPUB23 coordinately control a drought signaling pathway by ubiquitinating cytosolic RPN12a in an ABA-independent manner. In this process, the two PUBs act as negative regulators in response to drought stress [34]. The atpub18-2atpub19-3atpub22atpub23 quadruple mutant exhibits enhanced tolerance to drought stress as compared with each atpub18-2atpub19-3 and atpub22atpub23 double mutant progeny; however, the stomatal behavior of the quadruple is almost identical to the atpub18-2atpub19-3 double mutant in the presence of ABA, $\mathrm{H}_{2} \mathrm{O}_{2}$, and calcium [33]. A major structural difference between AtPUB18/AtPUB19 and AtPUB22/AtPUB233 is the presence or absence of the U-box N-terminal domain (UND), which is a determinant of substrate specificity. UNDPUB18 is critical in the negative regulation of ABA-mediated stomatal movements, and Exo70B1, a subunit of the exocyst complex, is a target of AtPUB18, whereas Exo70B2 is a substrate of AtPUB22 [35]. AtUBC32, AtUBC33, and AtUBC34 comprise group XIV E2 ubiquitin-conjugating enzymes, are colocalized with AtPUB19 to the punctate-like structures in Arabidopsis. Suppression of AtUBC32, AtUBC33, and AtUBC34 results in increased ABA-mediated stomatal closure and strengthened tolerance to drought stress [36].

Table 2. PUBs Function as Positive or Negative Regulators in the Response to Abiotic Stress.

\begin{tabular}{ccccccc}
\hline Gene & Abiotic Stress & $\begin{array}{c}\text { Biological } \\
\text { Roles }\end{array}$ & $\begin{array}{c}\text { Upstream } \\
\text { Regulator }\end{array}$ & $\begin{array}{c}\text { Interactor/ } \\
\text { Substrate }\end{array}$ & $\begin{array}{c}\text { Transgenic } \\
\text { Plants }\end{array}$ & References \\
\hline AtPUB11 & ABA, drought & Negative & - & LRR1, KIN7 & Arabidopsis, & {$[32]$} \\
\hline $\begin{array}{c}\text { AtPUB18, } \\
\text { AtPUB19 }\end{array}$ & ABA, drought & Negative & - & Exo70B1 & Arabidopsis & {$[33]$} \\
\hline $\begin{array}{c}\text { AtPUB2, } \\
\text { AtPUB23 }\end{array}$ & Drought & Negative & - & $\begin{array}{c}\text { RPN12a, } \\
\text { Exo70B2 }\end{array}$ & Arabidopsis & {$[34,35]$} \\
\hline $\begin{array}{l}\text { OsPUB41 } \\
\text { ABA, drought }\end{array}$ & Negative & OsUBC25 & OsCLC6 & Rice & [37] \\
\hline OsPUB67 & Drought & Positive & - & $\begin{array}{c}\text { OsRZFP34, } \\
\text { OsDIS1 }\end{array}$ & Rice & [38] \\
\hline
\end{tabular}


Table 2. Cont.

\begin{tabular}{|c|c|c|c|c|c|c|}
\hline Gene & Abiotic Stress & $\begin{array}{l}\text { Biological } \\
\text { Roles }\end{array}$ & $\begin{array}{l}\text { Upstream } \\
\text { Regulator }\end{array}$ & $\begin{array}{l}\text { Interactor/ } \\
\text { Substrate }\end{array}$ & $\begin{array}{l}\text { Transgenic } \\
\text { Plants }\end{array}$ & References \\
\hline $\begin{array}{l}\text { GmPUB6, } \\
\text { GmPUB8 }\end{array}$ & Drought & Negative & - & - & Arabidopsis & {$[17,39]$} \\
\hline StPUB27 & Drought & Negative & - & - & Potato & [32] \\
\hline \multirow[t]{2}{*}{ СаРUB1 } & Drought, salt & Negative & - & - & $\begin{array}{l}\text { Arabidopsis, } \\
\text { rice }\end{array}$ & {$[40,41]$} \\
\hline & Cold & Positive & - & - & Rice & [40] \\
\hline \multirow{2}{*}{ ТаРUB1 } & Drought, salt & Positive & - & - & $\begin{array}{c}\text { Arabidopsis, } \\
\text { wheat, } \\
\text { tobacco }\end{array}$ & [42-44] \\
\hline & $\mathrm{Cd}$, IAA & Positive & - & $\begin{array}{l}\text { TaIRT1, } \\
\text { TaIAA17 }\end{array}$ & Wheat & [45] \\
\hline PbrPUB18 & Drought & Positive & - & - & Arabidopsis & [23] \\
\hline PalPUB79 & Drought & Positive & PalWRKY77 & PalWRKY77 & Poplars & [46] \\
\hline PnSAG1 & ABA, salt & Negative & - & - & $\begin{array}{l}\text { Arabidopsis, } \\
\text { Physcomitrella } \\
\text { patens }\end{array}$ & [47] \\
\hline AtPUB30 & Salt & Negative & - & BKI1 & Arabidopsis & [48] \\
\hline ТaPUB15 & Salt & Positive & - & - & Arabidopsis & [49] \\
\hline ТаРUB26 & Salt & Negative & - & - & $\begin{array}{l}\text { Wheat, } \\
\text { Brachy- } \\
\text { podium }\end{array}$ & [50] \\
\hline AtPUB48 & Heat & Positive & - & - & Arabidopsis & [51] \\
\hline SICHIP & Heat & Positive & - & - & Tomato & [52] \\
\hline $\begin{array}{l}\text { AtPUB25, } \\
\text { AtPUB26 }\end{array}$ & Cold & Positive & AtOST1 & AtMYB15 & Arabidopsis & [53] \\
\hline VpРUВ24 & Cold & Positive & VpICE1 & VpHOS1 & Arabidopsis & {$[54,55]$} \\
\hline $\begin{array}{l}\text { CrPUB5 } \\
\text { CrPU14 }\end{array}$ & $\begin{array}{l}\text { Nitrogen } \\
\text { starvation }\end{array}$ & Negative & - & - & C. reinhardtii & [11] \\
\hline $\begin{array}{l}\text { CrPUB11, } \\
\text { CrPUB23, } \\
\text { CrPUB28 }\end{array}$ & $\begin{array}{l}\text { Nitrogen } \\
\text { starvation }\end{array}$ & Positive & - & - & C. reinhardtii & [11] \\
\hline
\end{tabular}

- , indicates unknown.

In rice, OsPUB41 and OsPUB67 play different roles in responding to drought. OsPUB41 is a cytosolic and nuclear localized PUB E3 ligase. OsPUB41 is specifically induced by dehydration and ABA treatments. The core U-box motif of OsPUB41 possesses the E3 ligase activity and can be activated by OsUBC25 [37]. The RNAi knockdown and ospub41 mutation plants exhibit enhanced tolerance to drought stress compared with the WT plants in terms of transpirational water loss, long-term dehydration response, and chlorophyll contents. The chloride channel protein OsCLC6 is a putative substrate of OsPUB41. Hence, OsPUB41 acts as a negative regulator of dehydration by interacting with a candidate substrate OsCLC6 [37]. OsPUB67 is significantly induced by drought, salt, cold, JA, and ABA, and expressed in the nuclei, cytoplasm, and membrane systems. OsPUB67 interacts with two drought tolerance negative regulators OsRZFP34 and OsDIS1 on the stomata, and improves drought tolerance by enhancing the ability of reactive oxygen (ROS) scavenging and stomatal closure [38]. Transcriptomic assays reveal that OsPUB67 participates in regulating the expressions of abiotic stress responsive genes in an ABA-dependent manner [38].

In Glycine max, 125 PUB genes are identified [17]. Among them, nine PUB proteins, GmPUB1-GmPUB 9, are involved in the response to water deficit. GmPUB6 is a peroxisome localized E3 ubiquitin ligase [39], while GmPUB8 is localized to post-Golgi compartments, interacting with GmE2 protein [17]. Both are induced by ABA, high salinity and water deficit. Overexpression of GmPUB6 and GmPUB8 results in decreased plant survival rates, 
reduced seed germination, retarded plant growth under osmotic stress, and suppressed ABA- or mannitol-mediated stomatal closure, relative to the WT control. Moreover, multiple stress responsive genes, including ABI1, DREB2A, KIN2, RAB18, RD20, RD29A and RD29B, are suppressed in transgenic plants under dehydration conditions [17,39].

TaPUB1 is a key regulator in the response to multiple adverse environmental stimuli in wheat. Constitutive expression of TaPUB1 in Nicotiana benthamiana leads to enhanced tolerance to water deficit relative to WT, which is verified by several improved morphological and physiological traits in transgenic lines, including higher seed germination, increased survival rates, strengthened photosynthetic, water retention and antioxidant abilities, and less ROS accumulation [42].

StPUB27 is a negative modulator of drought tolerance in potato. Overexpression StPUB27 causes increased stomatal conductance and results in accelerated water loss of detached leaves compare to the non-transgenic control. However, the RNA interference plants show a phenotype of smaller stomatal conductance and higher water retention capability, indicating that StPUB27 negatively regulate the response to drought stress by controlling stomata aperture in potato [32].

CaPUB1 is a PUB member in hot pepper (Capsicum annuum L.). Ectopic expression of $\mathrm{CaPUB1}$ in Arabidopsis and rice results in hypersensitive phenotypes to drought stress, with lower survival rates and chlorophyll contents than WT [40,41]. Furthermore, the expression of $R D 29 a$, a typical drought-induced gene, is substantially suppressed in transgenic Arabidopsis compared to the WT plants [41]. Hence, CaPUB1 functions as a negative regulator in the response to drought stress in both Arabidopsis and Rice [40,41].

PalPUB79 is significantly induced by drought, salinity and ABA signaling in Populus alba L. PalPUB79 overexpression confers enhanced drought tolerance in transgenic poplars, and this phenotype is eliminated in the absence of ABA signaling. However, PalPUB79 RNAi lines are more sensitive to drought stress compared to WT [46]. Furthermore, PalPUB79 interacts with PalWRKY77, a negative transcriptional regulator (TF) of ABA signaling, and mediates its ubiquitination for degradation, thus neutralizing the inhibitory effect on the expression of PalRD26, a drought responsive marker gene. In turn, PalWYKY77 directly down-regulates PalPUB79 expression by binding to the W-box (PW2) in the PalPUB79 promoter [46]. However, the inhibition can be reversed by adding PalPUB79 in dual-luciferase assay systems, suggesting that a negative feedback loop between PalWRKY77 and PalPUB79 during ABA signaling in poplar [46].

PbrPUB18 is a nucleus-localized PUB protein in pear (Pyrus bretschneideri L.). Heterologous expression of PbrPUB18 confers enhanced drought tolerance in Arabidopsis, manifested by light leaf-wilting symptoms and a serial of improved physiological traits related to drought tolerance, including enhanced photosynthetic ability, strengthened cell membrane stability, less accumulation of malondialdehyde and ROS. Thus, PbrPUB18 plays a positive role in the response to water deficit [23].

\subsection{PUBs Are Key Components in the Response to Salt Stress}

High soil salinity is one of major limitations for crop yield and production. Approximately $40 \%$ of irrigated lands worldwide are affected by increased salt levels, and the expansion of soil salinization is a serious threat to crop performance [56]. Solid data have shown that PUB E3 ligases are indispensable components in salt stress responses in plants.

PnSAG1 is an ARM-domain containing PUB in Antarctic moss Pohlia nutans, which is rapidly induced by exogenous ABA, salt, cold and drought stresses [47]. The PnSAG1overexpressing Arabidopsis lines exhibit more sensitive to ABA and salt stress during seed germination and early root growth. Similarly, heterogeneous expression of PnSAG1 in Physcomitrella patens causes hypersensitive to ABA and high salinity in gametophyte growth [47]. Gene expression assays show that the expression of salt stress/ABA-related genes are dramatically down-regulated in PnSAG1 transgenic plants under salt stressed conditions. Therefore, PnSAG1 plays negative roles in the responses to ABA and salt treatments [47]. 
In Arabidopsis, AtPUB30 participates in salt stress response at seed germination stage in an ABA-independent manner [57]. The Atpub30 mutant shows more tolerance to salt stress in seed germination relative to WT, whereas the mutant of its closest homolog AtPUB31 shows mild sensitivity to salt stress. AtPUB30 specifically interacts with and ubiquitinates BRI1 kinase inhibitor 1 (BKI1), a regulator playing dual roles in BR signaling, and degrades BKI1 via UPS. The bki1 mutant was sensitive to salt, whereas the BKI1 transgenic plants present a salt-tolerant phenotype. In sum, AtPUB30 negatively regulates salt tolerance probably through regulating the degradation of BKI1 in BR-signaling pathway [48].

Several wheat PUBs are identified as salt responsive regulators. TaPUB1 overexpression results in the up-regulation of ion channel genes in rice, tobacco and wheat under high salinity conditions, causing substantial increase of net root $\mathrm{Na}^{+}$efflux and decreases in net $\mathrm{K}^{+}$efflux and $\mathrm{H}^{+}$influx, therefore maintaining lower cytosolic $\mathrm{Na}^{+} / \mathrm{K}^{+}$ratios in transgenic plants relative to the non-transgenic plants [42-44,49]. Furthermore, TaPUB1 promotes the expression of some salt responsive genes and enhances the antioxidant capacity under salt stress. Consistent with this, the RNAi-mediated knockdown plants show an opposite phenotype to salt stress. Moreover, TaPUB1 interacts with TaMP ( $\alpha$-mannosidase protein), an important regulator of salt response in both yeast cells and plants. In short, TaPUB1 positively regulates salt tolerance by interacting with $\alpha$-mannosidase in plants [42-44,49].

TaPUB15 is an ortholog of OsPUB15 and induced by salt, ABA, low temperature, and water deficit. Overexpression of TaPUB15 causes substantial up-regulations of several salt induced genes and decreased $\mathrm{Na}^{+} / \mathrm{K}^{+}$ratios relative to $\mathrm{WT}$, and therefore confers pronounced salt tolerance in transgenic rice. These results are also verified in transgenic Arabidopsis, demonstrating TaPUB15 plays a role in enhancing salt tolerance in both monocot and dicot species [49]. TaPUB26 is induced by high salinity, cold, drought and phytohormones. Ectopic expression of TaPUB26 in Brachypodium distachyon leads to a hypersensitive phenotype to salt stress, manifested by reduced chlorophyll contents, decreased photosynthetic capabilities and antioxidant enzyme activities, more ROS accumulation and severer cell membrane damage relative to the WT plants [50]. Moreover, the transgenic plants have higher $\mathrm{Na}^{+}$contents and lower $\mathrm{K}^{+}$contents following salt treatment, hence maintain a higher cytosolic $\mathrm{Na}^{+} / \mathrm{K}^{+}$ratio in plant cells. Moreover, TaPUB26 interacted with TaRPT2a, an ATPase subunit of the $26 \mathrm{~S}$ proteasome complex, suggesting that it might modulate salt response by interacting with and ubiquitinating TaRPT2a [50].

The hot pepper CaPUB1 is also involved in the response to salt stress. Its overexpression causes a hypersensitive phenotype to salt stress in Arabidopsis. Both germination and post-germination growth of CaPUB1 transgenic plants are severely inhibited by mild salinity, while the WT plants are only slightly suppressed. Moreover, WT and transgenic plants display similar sensitivity to exogenous ABA in seed germination, consistent with its irresponsive expression to $\mathrm{ABA}$, suggesting that the negative response to salt stress mediated by CaPUB1 is ABA-independent [41].

\subsection{PUBs Are Key Regulators in the Response to Extreme Temperatures}

Extreme temperatures, including heat and cold/freezing, seriously affects plant growth, development and geographical distributions. Increasing data have shown that PUB proteins are implicated in the response to extreme temperatures in different plant species (Table 2).

AtPUB48 is a nucleus-localized PUB E3 ligase. Its overexpression leads to enhanced thermotolerance in seed germination and seedling growth in Arabidopsis, with remarkably enhanced transcription of several heat responsive genes, including HSP101, HSP70, HSP25.3, HSFA2, and ZAT12. In line with this, disruption of AtPUB48 causes a reduced germination rate relative to WT under high temperature conditions, and the expression levels of the heat responsive genes are dramatically reduced. Therefore, AtPUB48 may target the unknown substrate receptor to $26 \mathrm{~S}$ proteasome proteolysis [51]. 
CHIP (Carboxyl Terminus of the HSC70-Interacting Protein) is a type of conserved chaperone-dependent PUB targeting misfolded proteins. SlCHIP is induced by high temperature and stress hormones in tomato. Silencing of SICHIP leads to a phenotype hypersensitive to high temperature, accompanied with reduced photosynthetic activity, elevated electrolyte leakage and accumulation of insoluble protein aggregates. The accumulated protein aggregates are highly ubiquitinated, hinting that other E3 ligases might be involved in the ubiquitination process. Overexpression of SlCHIP restores the phenotype of the slchip mutant under heat-stressed conditions. Thus, SICHIP might modulate thermotolerance by targeting the degradation of misfolded proteins produced during heat stress [58].

Cold and freezing stresses adversely affect plant growth, development, and crop productivity and quality. AtPUB25 and AtPUB26 are two positive regulators of freezing tolerance in Arabidopsis. Both can poly-ubiquitinate AtMYB15, a transcriptional repressor of the CBF-dependent cold signaling pathway, leading to its degradation and thus enhancing CBF expression under cold stress. Furthermore, cold-activated OST1 can specifically phosphorylate AtPUB25 and AtPUB26 at conserved threonine residues, enhance their E3 ligase activity, and facilitate the cold-induced degradation of AtMYB15. Collectively, the AtOST1-AtPUB25/26 module regulates the duration and intensity of cold response by controlling the homeostasis of AtMYB15 [53].

VpPUB24 is a PUB member in the Chinese wild grapevine (Vitis pseudoreticulata), and implicated in the responses to several abiotic stresses, especially cold [55]. ICE1 (inducer of $\mathrm{CBF}$ expression 1) is an upstream TF regulating the expression of $\mathrm{CBF}$ genes under cold stress [54]. VpICE1 is targeted for degradation via the $26 \mathrm{~S}$ proteasome, and the degradation is accelerated by VpHOS1, but not by VpPUB24. Immunoblot data show that VpPUB24 promotes the accumulation of VpICE1, and suppresses the expression of VpHOS1 to regulate the abundance of VpICE1 [55]. Furthermore, VpICE1 promotes the transcription of VpPUB24 at low temperatures. Moreover, VpPUB24 interacts with VpHOS1 in yeast cells, hinting that VpPUB24 might ubiquitinate VpHOS1. Overexpression of VpPUB24 confers enhanced cold tolerance in Arabidopsis. Taken together, VpPUB24, VpICE1 and VpHOS1 form a complex module to regulate cold stress response [55].

CaPUB1 is a multifaceted PUB E3 ligase in hot pepper. The CaPUB1 transgenic rice lines present a tolerant phenotype to prolonged cold stress compared with the WT plants, with higher survival rates and chlorophyll contents, and less electrolyte leakage. Furthermore, several cold stress-induced marker genes, including DREB1A, DREB1B, DREB1C, and Cytochrome P450, are significantly induced by cold stress in transgenic lines than in the WT plants. Hence, CaPUB1 acts as a positive regulator of cold stress in transgenic rice [40]

\subsection{TaPUB1 Is an Essential Regulator of Heavy Metal Tolerance}

Heavy metals, including cadmium, silver and mercury, dramatically affect plant growth and development. Heavy metals in the soil are absorbed by plant roots and accumulate in aerial tissues, which seriously retards several molecular and physiological processes. $\mathrm{Cd}^{2+}$ is one of the most deleterious heavy metal pollutants. Recent progress shows that TaPUB1 is implicated in regulating $\mathrm{Cd}^{2+}$ absorption in wheat. The transcription of TaPUB1 is significantly induced by $\mathrm{Cd}$ stress and indole acetic acid (IAA) treatment [45]. Wheat plants overexpressing TaPUB1 show significantly reduced $\mathrm{Cd}^{2+}$ uptake and accumulation, whereas RNAi plants exhibited a substantial increase in $\mathrm{Cd}^{2+}$ accumulation following $\mathrm{Cd}$ treatment. Protein interaction results show that TaPUB1 interacts with and ubiquitinates TaIRT1, a $\mathrm{Cd}^{2+}$ transporter, resulting in the inhibition of $\mathrm{Cd}^{2+}$ uptake, decreased ROS accumulation and down-regulated antioxidant enzyme activities under $\mathrm{Cd}$-stressed conditions. Furthermore, TaPUB1 directly interacts with and ubiquitinates TaIAA17, facilitating its degradation, thus releases the inhibition on roots and fuels primary root elongation by activating the auxin signaling pathway under Cd stress [45]. 


\subsection{PUBs Are Implicated in the Response to Nitrogen Starvation}

Nitrogen is an important nutrient element that influences lipid/carbohydrate accumulation in microalgae [59]. In total of $30 \mathrm{CrPUB}$ genes, 25 are involved in the response to nitrogen starvation in C. reinhardtii. Among them, 18 CrPUBs are induced by $\mathrm{N}$-deficit, and seven are inhibited, revealing that CrPUBs are widely involved in the response to $\mathrm{N}$-starvation. Furthermore, silencing of CrPUB5 and CrPU14 causes significant lipid accumulations under N-deplete conditions, whereas knockdown of CrPUB11, CrPUB23 and CrPUB28 results in substantial reduction of lipid accumulation, indicating the intensive involvements of CrPUBs in oil metabolism under N-starvation [11].

\section{PUB E3 Ligases Are Pivotal Regulators in the Response to Biotic Stress}

Plants are constantly exposed to a variety of pathogen factors. To survive plants have developed numerous mechanisms to cope with the challenges. PUB E3 ligases are key components of diverse signaling pathways in the responses to pathogen attacks.

In Arabidopsis, several PUB proteins have been identified as immunity modulators (Table 3). Convincing data show that the closely related AtPUB12 and AtPUB13 are involved in response to pathogen infections. The Arabidopsis pattern-recognition receptor Flagellin Sensing 2 (FLS2) recognizes bacterial flagellin and initiates immune signaling through association with BAK1. BAK1 phosphorylates AtPUB12 and AtPUB13 and is required for FLS2-PUB12/13 association. AtPUB12 and AtPUB13 polyubiquitinate FLS2 and promote flagellin-induced FLS2 degradation, which in turn attenuates FLS2 signaling to prevent excessive or prolonged activation of immune responses [26,60]. Moreover, AtPUB13 is also implicated in innate immunity [61,62]. Disruption of AtPUB13 causes spontaneous cell death, accumulated of $\mathrm{H}_{2} \mathrm{O}_{2}$ and salicylic acid (SA), and enhanced resistance to biotrophic pathogens, but increased the susceptibility to necrotrophic pathogens. SID2 (SA-induction deficient 2) and PAD4 (Phytoalexin deficient 4) are required in SA-mediated disease resistance [61]. AtPUB25 and AtPUB26 negatively regulate the defense against hemibiotrophic pathogen Verticillium dahlia by degrading the positive regulator AtMYB6, which promotes plant resistance to Verticillium wilt. Mutation of AtPUB25 and AtPUB26 leads to strengthened resistance to Verticillium. VDAL is a Verticillium dahliae-secreted Asp f2-like protein and competes with AtMYB6 for binding to PUBs and reducing hypersensitive response (HR) caused by infection, thus keep host plant alive. Alternatively, hemibiotrophic pathogens may take nutrients from host cells [63].

Table 3. PUBs Involved in the Response to Pathogen Attacks.

\begin{tabular}{ccccccc}
\hline Gene & $\begin{array}{c}\text { Pathogen } \\
\text { Factors }\end{array}$ & $\begin{array}{c}\text { Biological } \\
\text { Roles }\end{array}$ & $\begin{array}{c}\text { Upstream } \\
\text { Regulator }\end{array}$ & $\begin{array}{c}\text { Interactor/ } \\
\text { Substrate }\end{array}$ & $\begin{array}{c}\text { Transgenic } \\
\text { Plants }\end{array}$ & References \\
\hline $\begin{array}{c}\text { AtPUB12, } \\
\text { AtPUB13 }\end{array}$ & Bacteria & Negative & BAK1 & FLS2 & Arabidopsis & [26,60] \\
\hline $\begin{array}{c}\text { AtPUB25, } \\
\text { AtPUB26 }\end{array}$ & $\begin{array}{c}\text { Verticillium } \\
\text { dahliae }\end{array}$ & Negative & - & AtMYB6 & Arabidopsis & [63] \\
\hline OsSPL11 & $\begin{array}{c}\text { Xanthomonas } \\
\text { oryzae, }\end{array}$ & Negative & - & SPIN6 & Rice & [64,65] \\
\hline OsPUB15 & $\begin{array}{c}\text { M. oryzae } \\
\text { OsPUB44 }\end{array}$ & Positive & Pid2 & - & Rice & [66] \\
\hline P3IP1 & $\begin{array}{c}\text { Rice grassyzae } \\
\text { stunt virus }\end{array}$ & Positive & - & XopP & Rice & [67] \\
\hline StPUB17 & $\begin{array}{c}\text { Phytophthora } \\
\text { infestans }\end{array}$ & Positive & - & OsNRPD1a & Rice & [68] \\
\hline GhPUB17 & \begin{tabular}{l} 
V. dahliae \\
\hline
\end{tabular} & Negative & GhCyP3 & - & Cotton & [69] \\
\hline
\end{tabular}


Table 3. Cont.

\begin{tabular}{|c|c|c|c|c|c|c|}
\hline Gene & $\begin{array}{l}\text { Pathogen } \\
\text { Factors }\end{array}$ & $\begin{array}{c}\text { Biological } \\
\text { Roles }\end{array}$ & $\begin{array}{l}\text { Upstream } \\
\text { Regulator }\end{array}$ & $\begin{array}{l}\text { Interactor/ } \\
\text { Substrate }\end{array}$ & $\begin{array}{c}\text { Transgenic } \\
\text { Plants }\end{array}$ & References \\
\hline МdPUB29 & $\begin{array}{c}\text { Botryosphaeria } \\
\text { dothidea }\end{array}$ & Positive & MdPOB1 & - & $\begin{array}{l}\text { Arabidopsis, } \\
\text { apple calli }\end{array}$ & [71] \\
\hline GmPUB1 & $\begin{array}{c}\text { Phytophthora } \\
\text { sojae }\end{array}$ & Positive & - & - & Soybean & [72] \\
\hline GmPUB13 & P. sojae & Negative & - & - & Soybean & [73] \\
\hline
\end{tabular}

In rice, several PUB E3 ligase are identified as critical regulators in disease resistance (Table 3). OsSPL11, an ortholog of AtPUB13, functions as a negative regulator of programmed cell death (PCD). Mutation of spl11 confers enhanced non-race-specific resistance to both Xanthomonas oryzae and Magnaporthe oryzae. OsSPL11 physically interacts with and ubiquitinates the GAP protein SPIN6 to suppress NADPH oxidase-mediated ROS generation and PR gene activation, therefore to inhibit the autoactivation of defense responses. The resistance is correlated with a constitutive activation of defense-related genes, including pathogenesis-related (PR) genes (PR1, PBZ1, chintinase III), oxalate oxidase genes involved in the production of $\mathrm{ROS}(\mathrm{HvO} \mathrm{OO} a, \mathrm{HvOxOLP})$, and genes encoding peroxidases (POX8.1, POX22.3) [74]. Moreover, SPL11 also negatively regulates SA accumulation, which might inhibit SA-mediated resistance and lead to susceptible to pathogen factors [65]. OsPUB15 is a major component of the transmembrane receptor-like kinase Pid2 mediated signaling pathway. Pid2 can phosphorylate OsPUB15, and the phosphorylated OsPUB15 has E3 ligase activity. OsPUB15 overexpressing rice plants display cell death lesions associated with constitutive activation of basal defense responses includes excessive accumulation of $\mathrm{H}_{2} \mathrm{O}_{2}$, up-regulation of disease-related genes, and increased resistance to $M$. oryzae spore strains [66]. OsPUB44 directly interacts with XopP (Xoo), an effector of pathogen X. oryzae. Silencing of OsPUB44 suppresses peptidoglycan- and chitin-triggered immunity, and the plants exhibit a susceptible phenotype to X. oryzae, indicating that OsPUB44 positively regulate immune responses by degrading XopP via UPS [67].

P3IP1 (P3 Induced Protein 1) is named for being induced by the P3 protein of rice grassy stunt virus (RGSV). Stable expression of P3 protein in rice leads to developmental abnormities similar to the disease symptoms caused by RGSV, such as dwarfism and excess tillering. Both transgenic expression of P3 and RGSV infection induce ubiquitination and UPS-dependent degradation of rice Nuclear RNA Polymerase D1a (OsNRPD1a), one of two orthologs of the largest subunit of plant-specific RNA polymerase IV, which is required for RNA-directed DNA methylation. P3IP1 interacts with and ubiquitinates OsNRPD1a, and mediates its degradation via UPS in vitro and in vivo. Knockdown of OsNRPD1 or overexpression of P3IP1 results in the phenotypes similar to RGSV disease symptoms in rice, thus P3IP1 negatively modulate the response to virus attacks [68].

StPUB17 is a nucleus-localized positive regulator of programmed cell death (PCD) triggered by resistance proteins CF4/9 in potato. Silencing StPUB17 in potato by RNAi and NbPUB17 in N. benthamiana by virus-induced gene silencing each enhanced the leaf colonization of Phytophthora infestans, because of attenuated PAMP-triggered immunity (PTI). Further data reveal that not all PTI- and PCD-associated responses require PUB17 [69]. Exclusion of the StPUB17 (V314I, V316I) mutant from the nucleus abolishes its dominantnegative activity, demonstrating that StPUB17 functions in the nucleus. Overall, StPUB17 is a positive regulator of immunity to late blight, acting in the nucleus to promote specific PTI and PCD pathways [69]. Ectopic expression of the Arabidopsis ortholog AtPUB17 in ACRE276-silenced tobacco plants rescues HR. The atpub17 mutant also displays decreased resistance to avirulent Pseudomonas syringae pv. tomato [75]. GhPUB17, an ortholog of StPUB17, is induced by the infection of $V$. dahliae or exogenous hormone treatment, including JA and SA in cotton. GhPUB17-knockdown cotton plants are more resistant to $V$. dahliae, conversely the overexpressing plants are more susceptible to the pathogen, indicating 
that GhPUB17 is a negative regulator of cotton resistance to V. dahlia. Cyclophilin protein GhCyP3 is an interactor of GhPUB17 with antifungal activity. The ubiquitination activity of GhPUB17 is inhibited by GhCyP3, an interactor of GhPUB17 with antifungal activity. GhCyP3 shows antifungal activity against $V$. dahliae, and the E3 ligase activity of GhPUB17 is repressed by GhCyP3 in vitro [70].

MdPUB29 is a PUB E3 ligase in apple, activated by the infection of fungal pathogen Botryosphaeria dothidea. Its overexpression results in enhanced resistance to $B$. dothidea infection in both Arabidopsis and apple calli. Consistent with this, silencing MdPUB29 resulted in reduced resistance in apple calli [71]. The defense process is accompanied with increased of $\mathrm{H}_{2} \mathrm{O}_{2}$ content and enhanced expressions of SA synthesis- and SA signalingrelated genes [71]. The BTB domain is a protein-protein interaction motif in eukaryotes. Many BTB domain-containing proteins play roles as substrate-specific adapters in cullin 3-based E3 ligases [76], and BTB domain proteins have been shown to associate with cullin 3 proteins to form ubiquitin E3 ligases [77]. The apple POZ/BTB Containing-protein 1 (MdPOB1), a BTB-BACK domain E3 ligase, suppresses apple pathogen defense against B. dothidea by directly interacting with and degrading MdPUB29 [78].

Oomycete pathogens such as Phytophthora secrete a repertoire of effectors into host cells to manipulate host immunity and benefit infection, including RxLR effectors Avr1b, Avr1d and Avr1k [72]. Several Phytophthora induced GmPUB proteins can interact with the RxLR effectors. Solid data have shown that Avr1b interacts with GmPUB1 in vivo and in vitro. The mutation in Avr1b C-terminus abolishes the interaction with GmPUB1 and the inhibition of cell death. Silencing of GmPUB1 in soybean cotyledons resulted in loss of recognition by the gene products of Avr1b [72]. Overexpression of GmPUB1 triggers cell death and enhanced resistance to Phytophthora, revealing that GmPUB1 is a positive regulator of effector-triggered immunity, and plays a positive role in the defense against Phytophthora [72]. Recent data show that Avr1d competes with E2 for GmPUB13 binding to repress the E3 ligase activity and stabilize GmPUB13 to facilitate Phytophthora infection [73]. Thus, GmPUB13 acts as a negative modulator in the infection process. Silencing of GmPUB13 in soybean hairy roots leads to decreased P. sojae infection [73].

NtCMPG1 is highly related to parsley CMPG1 (designated according to the four conserved amino acids, Cys, Met, Pro and Gly) and AtPUB20 and AtPUB21. NtCMPG1 and the homolog of tomato SlCmpg1 are induced by Avr9 elicitation. Silencing of NtCMPG1 leads to reduced HR after Cf-9/Avr9 elicitation, while overexpression of NtCMPG1 induces a stronger HR in Cf9 tobacco plants post-Avr9 infiltration. In tomato, silencing of SlCmpg1 decreases the resistance to Cladosporium fulvum, while overexpression of epitope-tagged NtCMPG1 mutated in the U-box domain confers a dominant-negative phenotype. Furthermore, NtCMPG1 is involved in the Pto/AvrPto and Inf1 responses. Therefore, NtCMPG1 is essential for plant defense and disease resistance [79]. CMPG1 is also required for PCD triggered by INF1 (the major elicitin secreted by P. infestans) in diverse plant species, and degraded via UPS [80]. The RXLR effector AVR3a of P. infestans targets and stabilizes host E3 ligase. In stabilizing CMPG1, AVR3a modifies its normal activity and exclusively suppresses CMPG1-dependent PCD [81], supporting a hypothesis that cytoplasmic effector targets CMPG1 to block the signal transduction and/or regulatory processes following perception of pathogen molecules.

\section{PUBs Are Multifaceted Modulators in Various Biological Processes}

\subsection{PUBs Control the Development of Roots and Root System Architecture}

The root system is a vital plant organ responsible for water absorption, nutrient forage, anchorage, propagation, and storage [82]. Root growth and differentiation are closely linked to plant hormones and shaped by various environmental factors, including nutrient starvation and different stress factors [83]. Compelling data have shown that a variety of PUB proteins are involved in regulating root development (Table 4). AtPUB4 is a novel downstream component of CLV3/CLE signaling pathway in the root meristem [84]. Mutation of AtPUB4 releases the inhibition of exogenous CLV3/CLE peptide on root cell proliferation and columella stem cell 
maintenance. Without exogenous CLV3/CLE peptide, the atpub4 mutants show enhanced root growth, increased cortex/endodermis stem cells and reduced columella layers [85]. Further phenotypic and gene expression assays reveal that AtPUB4 promotes the expression of cell cycle regulatory gene $C Y C D 6 ; 1$, and regulates formative periclinal asymmetric cell divisions in endodermis and cortex/endodermis initial daughters [85].

Table 4. PUBs Participate in Plant Growth and Development.

\begin{tabular}{|c|c|c|c|c|c|c|}
\hline Gene & Plant Traits & $\begin{array}{l}\text { Biological } \\
\text { Roles }\end{array}$ & $\begin{array}{l}\text { Upstream } \\
\text { Regulator }\end{array}$ & $\begin{array}{l}\text { Interactor/ } \\
\text { Substrate }\end{array}$ & $\begin{array}{l}\text { Transgenic } \\
\text { Plants }\end{array}$ & References \\
\hline AtPUB9 & Lateral root & Positive & - & - & Arabidopsis & {$[86]$} \\
\hline TaPUB1 & $\begin{array}{c}\text { IAA, root } \\
\text { development }\end{array}$ & Positive & - & TaIAA17 & Wheat & {$[45]$} \\
\hline ТаРUB15 & $\begin{array}{c}\text { Root } \\
\text { development }\end{array}$ & Positive & - & - & Rice & [49] \\
\hline OsPUB15 & $\begin{array}{l}\text { Root and shoot } \\
\text { development }\end{array}$ & Positive & - & - & Rice & [87] \\
\hline CaPUB1 & $\begin{array}{c}\text { Root } \\
\text { development }\end{array}$ & Positive & - & - & Arabidopsis & [41] \\
\hline GmPUB6 & $\begin{array}{c}\text { Seed germination, } \\
\text { root } \\
\text { development }\end{array}$ & Negative & - & - & Arabidopsis & [39] \\
\hline SAUL1 & Leaf senescence & Positive & - & $\mathrm{AAO} 3$ & Arabidopsis & [88] \\
\hline AtUSR1 & Leaf senescence & Positive & MYC2 & - & Arabidopsis & [89] \\
\hline AtPUB13 & Flowering & Negative & - & - & Arabidopsis & [61] \\
\hline OsSPL11 & Flowering & Positive & - & RBS1 & Rice & [90] \\
\hline GmPUB8 & Flowering & Positive & - & - & Arabidopsis & [17] \\
\hline MdPUB29 & $\begin{array}{c}\text { Ethylene } \\
\text { production, } \\
\text { Fruit ripening, } \\
\text { leaf senescence }\end{array}$ & Positive & MdbHLH3 & - & Apple & [91] \\
\hline VIPUB38 & Fruit ripening & Negative & - & VlAAO & Grape & [92] \\
\hline \multirow[t]{2}{*}{ AtPUB4 } & $\begin{array}{l}\text { Tamen } \\
\text { development, } \\
\text { male fertility, }\end{array}$ & Positive & - & - & Arabidopsis & {$[93,94]$} \\
\hline & cell division & Negative & - & - & Arabidopsis & [85] \\
\hline OsPUB73 & $\begin{array}{l}\text { Tapetal and } \\
\text { pollen exine } \\
\text { development }\end{array}$ & Positive & - & - & Rice & [95] \\
\hline$A R C 1$ & $\begin{array}{c}\text { Self- } \\
\text { incompatibility }\end{array}$ & Positive & SRK & - & Brassica & {$[96,97]$} \\
\hline DSG1 & $\begin{array}{l}\text { cell division and } \\
\text { elongation }\end{array}$ & Positive & - & - & Rice & [98] \\
\hline LIN & $\begin{array}{c}\text { nodule } \\
\text { primordium } \\
\text { development }\end{array}$ & Positive & - & - & $\begin{array}{l}\text { Medicago } \\
\text { truncatula, } \\
\text { Lotus } \\
\text { japonicus }\end{array}$ & [99] \\
\hline MtPUB1 & Nodulation & Negative & LYK3 & - & $\begin{array}{c}\text { M. } \\
\text { truncatula }\end{array}$ & {$[100]$} \\
\hline MtPUB2 & $\begin{array}{l}\text { Nodulation } \\
\text { homeostasis }\end{array}$ & Negative & MtDMI2 & - & $\begin{array}{c}\text { M. } \\
\text { truncatula }\end{array}$ & [101] \\
\hline
\end{tabular}

- , indicates unknown

AtPUB9 is required for lateral root formation under phosphate starvation conditions. AtPUB9 localizes to autophagic bodies following either activation by S-Domain receptor kinase (ARK2) or under phosphate deficit. The ark2-1/pub9-1 double mutants display defects in lateral root development and auxin accumulation in the root tips under phos- 
phate deprived conditions [86]. Blocking autophagic responses in WT Arabidopsis results in the inhibition of lateral roots and auxin accumulation in the root tips. It is hypothesized that ARK2/AtPUB9 module might regulate lateral root development using selective autophagy [86].

TaPUB1 is significantly induced by IAA, and its overexpression results in strengthened photosynthetic capability and increased root length than the non-transgenics. Protein interaction assays show that TaPUB1 directly interacts with and ubiquitinates TaIAA17, facilitating its degradation via UPS, and results in primary root elongation by activating the auxin signaling pathway [45]. Constitutive expression of TaPUB15 confers more and longer crown root phenotype, and pronounced salt tolerance in rice [49]. Mutation of the rice ortholog OsPUB15 causes a phenotype of primary root loss and delayed shoot development [87], indicating that both TaPUB15 and OsPUB15 are positive regulators in root development.

Moreover, heteroexpression of CaPUB1 in Arabidopsis leads to markedly longer hypocotyls and roots and more vigorous growth than WT. Microscopic analysis shows that the roots of CAPUB1 transgenic plants have more small-sized cells, resulting in disordered, highly populated cell layers in the cortex, endodermis, and stele [41].

\subsection{PUBs Promote Leaf Senescence via Various Phytohormone Signaling Pathways}

Leaf senescence is an active nutrient relocation process regulated by aging, flowering, darkness, nutrient starvation, and environmental stress. Several phytohormones are involved in regulating leaf senescence, including ABA, ethylene, SA and JA. Accumulated data have manifested that PUBs are key modulators in cell senescence via different signaling pathways (Table 4).

Senescence-Associated E3 Ubiquitin Ligase 1 (SAUL1) is a star member in regulating leaf senescence. Its mutation leads to premature senescence under low light conditions in Arabidopsis, with a phenotype of yellow leaves, decreased chlorophyll contents, and accompanied by increased ABA content and enhanced expression of senescence related genes. Aldehyde oxidase 3 (AAO3) is a key enzyme responsible for converting abscisicaldehyde to ABA [102]. SAUL1 interacts AAO3 in vitro. Mutation of SAUL1 results in the accumulation of AAO3 protein and thus enhances its activity in saul1 mutants. It is hypothesized that SAUL1 prevents senescence from occurring prematurely by targeting AAO3 for degradation and suppressing ABA production [88].

Transcription factor ORESARA1 (ORE1) is a key regulator of age-dependent leaf senescence and cell death in Arabidopsis. The accumulation of ORE1 transcripts is induced by low light treatment in saul1 mutants, along with the enhanced expression of senescence marker gene Senescence-Associated-Gene 12 (SAG12) and cell death. However, the accumulation of ORE1 is not sufficient to cause saul1 phenotypes, as demonstrated by double mutant analysis. Exposure of saul1 mutants to low light for $24 \mathrm{~h}$ does not cause visible senescence symptoms; however, the senescence-promoting TF genes WRKY53, WRKY6, and NAC-LIKE ACTIVATED BY AP3/PI are up-regulated, indicating the initiation of senescence in saul1 seedlings. Transcriptomic data reveal that SA might play a central role in saul1 senescence and cell death, which is verified by increased SA content in low-light-treated saul1 mutants, and application of exogenous SA triggers saul1 senescence in permissive light conditions. Furthermore, saul1 senescence depends on the PAD4-dependent SA pathway [103].

AtUSR1 (U-box Senescence Related 1) encodes a PUB protein. Its transcription is promoted by MYC2 TF in JA signaling pathway. Overexpression of AtUSR1 in the myc 2 mutant plants show precocious senescence, while myc 2 mutant displays a phenotype of delayed leaf senescence, suggesting that AtUSR1 functions downstream to MYC2 in the JA signaling pathway in promoting leaf senescence [89].

Additionally, AtPUB13 transgenic plants and the pub12pub13 mutant are more sensitive to stress-induced leaf senescence accompanied by elevated expression of stress-induced senescence marker genes [104]. Therefore, PUB genes are widely involved in the process of senescence. 


\subsection{PUBs Are Required in Controlling Flowering Time}

AtPUB13 is an essential flowering regulator in Arabidopsis. The atpub13 mutant shows a phenotype of early flowering under middle- and long-day conditions, in which the expressions of SOC1 (Suppressor of Overexpression of Constants 1) and Flowering Locus T (FLT) are induced, while Flowering Locus C (FLC) expression is suppressed. The two components involved in the SA-mediated signaling pathway, SID2 and PAD4, are required for flowering-time control. Briefly, AtPUB13 acts as an important node connecting SA-dependent defense signaling and flowering-time regulation in Arabidopsis [61].

OsSPL11, a homolog of AtPUB13 in rice, employs a different pathway to control flowering time, by interacting with the novel RNA/DNA binding KH domain protein SPIN1. Overexpression of SPIN1 causes late flowering in transgenic rice under both shortand long-day conditions. RNA-binding and SPIN1-interacting 1 (RBS1) protein binds RNA in vitro and interacts with SPIN1 in the nucleus. RBS1 overexpression represses the expression of $H d 3 a$ and causes delayed flowering under both short- and long-day conditions [90]. Interestingly, the expression of SPIN1 is increased, while OsSPL11 is repressed in the RBS1 overexpression plants. Moreover, RBS1 is up-regulated in both SPIN1 overexpressing plants and the osspl11 mutant. Collectively, OsSPL11 modulates flowering time by interacting with SPIN1, the positive regulator of RBS1; while RBS1 inhibits flowering by represses the expression of $\mathrm{Hd} 3 a$ in rice [90].

In addition, GmPUB8 participates in controlling flowering by interacting with COL (Constans Like) protein in soybean. GmPUB8-overexpressing Arabidopsis plants show an early flowering phenotype under middle- and short-day conditions, but delayed flowering under long-day conditions, indicating that GmPUB8 might regulate flowering time via the photoperiod pathway [17].

\subsection{PUBs Participate in Fruit Development and Ripening via the Phytohormone- Dependent Pathways}

Fruit ripening is a complicated process involving different phytohormones and various environmental stimuli. Fruit were classified into climacteric and nonclimacteric based on the patterns of respiration and ethylene production during fruit maturation and ripening [105]. Accumulated data have shown that PUBs are involved in the ripen of both climacteric and nonclimacteric fruit (Table 4).

Apple MdbHLH3 is an anthocyanin-related basic helix-loop-helix TF. It binds to the promoters of ethylene biosynthesis genes $M d A C O 1, M d A C S 1$, and $M d A C S 5 A$, activating their transcriptions and promoting ethylene biosynthesis. Overexpression of $M d b H L H 3$ leads to the enhancement of ethylene production, premature leaf senescence, and apple fruit ripening [91]. MdPUB29 can directly ubiquitinate MdbHLH3 guiding its degradation via UPS, therefore inhibit the expressions of ethylene biosynthetic genes, ethylene production and apple fruit ripen, demonstrating that MdPUB29 is implicated in controlling climacteric fruit ripen [91].

Recent studies have revealed that PUBs also involved in the ripen of nonclimacteric fruit. For instance, VlPUB38 is a PUB member in grape. Its overexpression results in delayed mature in strawberry. However, this phenotype can be rescued by applying exogenous ABA and the inhibitor of $26 \mathrm{~S}$ proteasome, MG132. Furthermore, VlPUB38 interacts with abscisic-aldehyde oxidase (VlAAO), targeting VlAAO proteolysis via UPS. Briefly, VlPUB38 negatively modulates grapefruit ripening by mediating the degradation of the key component VIAAO in the ABA synthesis pathway [92].

Moreover, transcriptome profiling also shows that the expression of 37-40 PUB genes in the pre-ripen and ripen peach fruit, hinting the intensive involvement of PUBs in fruit development and ripen [22]. 


\subsection{Multiple PUBs Are Key Regulators of Sexual Reproduction in Flowering Plants}

Accumulated data have shown that PUB E3 ligases are vital modulators in the sexual reproduction of flowering plants, including male sterility and self-incompatible (Table 4). Male sterility is generally characterized by the impairment of the male reproductive development as a result of underlying genetic causes and leads to the malformation of male gametes and/or pollen, or unable release. Pollen formation is a complex developmental process that has been extensively investigated. AtPUB4, a U-box/ARM repeat-containing E3 ligase, is a novel player in male fertility in Arabidopsis. Loss function of AtPUB4 causes hypertrophic growth of the tapetum layer, incomplete degeneration of tapetal cells and strikingly abnormal exine structures of pollen grains. Although the atpub4 mutant produces viable pollen, the pollen grains adhere to each other and to the remnants of incompletely degenerated tapetal cells, and do not properly disperse from dehisced anthers for successful pollination. Further studies indicates that the mutation caused sterile is temperature-dependent. The atpub4 mutant plants are completely sterile at $22{ }^{\circ} \mathrm{C}$, but partially fertile at $16{ }^{\circ} \mathrm{C}$ [93]. Recent research has shown that AtPUB4, along with AtPUB2, interacts with Extra-Large G Proteins (XLGs) and might function in the complex cytokininsignaling networks. The atpub4 mutant, the atpub2/4 double mutant, and at $x$ lg $1 / 2 / 3$ triple mutant all exhibits defects in cytokinin responses, stamen and tapetum development, and male fertility [94]. Overexpressing $A R R 10$, a positive regulator gene of cytokinin signaling, to enhance the cytokinin response in atpub4 or in the atxlg $1 / 2 / 3$ triple mutant partially restore several phenotypes caused by the atpub4 and at $x \lg 1 / 2 / 3$ mutations [94].

In rice, the ospub73 mutant displayed significant lower pollen fertility (19.45\%) relative to WT $(85.37 \%)$. Cytological evidence shows that the tapetum of ospub73 mutant is vacuolated at the meiosis stage, and the pollen exine is abnormal at the bi-cellular pollen stage. Transcriptomic assays show that seven known genes associated with tapetal cell death or pollen exine development are down-regulated, including CYP703A3 (Cytochrome P450 Hydroxylase703A3), CYP704B2 (Cytochrome P450 Hydroxylase704B2), DPW (Defective Pollen Wall), PTC1 (Persistent Tapetal Cell1), UDT1 (Undeveloped Tapetum1), OsAP37 (Aspartic Protease37) and OsABCG15 (ATP Binding Cassette G15), suggesting that OsPUB73 play an important role in tapetal or pollen exine development [95].

Self-incompatibility (SI) is one of the most important mechanisms to prevent selffertilization and generate genetic diversity within flowering plant species. The SI response is comprised of a self- and non-self-recognition process between pollen and pistil following a selective inhibition of the self-pollen (tube) development. The self-/non-self-recognition in most species is controlled by a single multiallelic S-locus. Pollen inhibition occurs when the same "S-allele" specificity is expressed by both pollen and pistil [106]. In the Brassicaceae, the self-pollen is recognized by the pollen S-locus cysteine rich/S-locus protein 11 (SCR/SP11) ligand and the pistil S receptor kinase (SRK). The SCR/SP11 ligand on the pollen surface binds to SRK on the pistil surface, and initiate the SRK-activated signaling pathway. The self-pollen is rejected by preventing pollen hydration following pollen contact with the stigmatic surface. The armadillo repeat-containing 1 (ARC1) protein, a member of the PUB E3 ubiquitin ligases, is involved in this signaling pathway. ARC1 is required downstream of SRK for the self-incompatibility response [96,97]. ARC1 can shuttle between the nucleus, cytosol, and proteasome/COP9 signalosome in tobacco BY-2 cells. However, ARC1 localization to the proteasome/CSN occurs only in the presence of an active SRK. Inhibition of the proteasomal proteolytic activity disrupts the SI response. Thus, ARC1 might propel the ubiquitination and proteasomal degradation of compatibility factors in the pistil, causing pollen rejection [97]. Subsequent studies have shown the deletion of ARC1 in many self-mating plant species, demonstrating that the conserved role for ARC1 in the self-pollen rejection response within the Brassicaceae [107]. 


\subsection{PUBs Are Involved in Regulating Cell Division}

Dwarf and Short Grain 1 (DSG1) encodes a nuclear- and cytoplasm-localized PUB E3 ligase in rice. Mutation of DSG1 cause a phenotype with shorter roots, internodes, panicles and seeds, and wider and curled leaves, due to defects in cell division and elongation [98]. Furthermore, the dsg1 mutant is less sensitive to BRs, and DSG1 expression is negatively regulated by BRs, ethylene, auxin, and SA. Collectively, DSG1 positively regulates cell division and elongation and is involved in multiple hormone pathways [98]. Additionally, AtPUB4 regulates asymmetric cell division and cell proliferation in the root meristem [85].

\subsection{PUBs Modulate Nodulation in Leguminous Plants}

The legume-rhizobia symbiosis is initiated by a signal exchange between host plants and soil bacteria. Root nodulation requires the dual activation of nodule organogenesis and infection processes, which depend on the perception of Rhizobial Nod factor (NFs), lipochitooligosaccharadic signals in the plant roots. Lumpy infections (LIN) is a PUB-type E3 ligase in Medicago truncatula, functions at an early stage of the Rhizobial symbiotic process, and is required for both infection thread growth in root hair cells and the further development of nodule primordia, mutation of LIN leads to a suppression of nodule development [99]. Receptor-like kinases (RLKs) play multiple roles in the perception of NFs and their transduction via calcium-mediated responses and transcriptional regulation [108]. LYK3 is a RLK of M. truncatula, which is essential for the establishment of the nitrogenfixing, root nodule symbiosis with Sinorhizobium meliloti. MtPUB1 is an interactor of the kinase domain in LYK3. Both are localized and interact in the plasma membrane of plants. MtPUB1 is induced by NFs and expresses specifically in symbiotic conditions, and shows an overlapping expression pattern with LYK3 during nodulation. MtPUB1 has ubiquitin ligase activity and is phosphorylated by the LYK3. Overexpression of MtPUB1 leads to a delay in nodulation with $S$. meliloti, suggesting that it is a negative regulator of nodulation [100]. Furthermore, the transcript level of $M t P U B 1$ is a specificity determinant of nodulation to Rhizobial species in a NF-dependent manner [100].

Does Not Make Infection 2 (MtDMI2) is a Leu rich repeat-type receptor kinase required for signal transduction in the M. truncatula/S. meliloti symbiosis pathway. MtPUB2 is a novel PUB-type E3 ligase, and can be phosphorylated at Ser-316, Ser-421, and Thr-488 residues by MtDMI2. The phosphorylation status of Ser421 is essential for the ubiquitination activity of MtPUB2. MtDMI2 can be persistently ubiquitinated by MtPUB2S421D (mimics the phosphorylated state) and degraded via UPS. However, the mutant MtPUB2S421A loses the ubiquitination function [101]. Further studies reveal that MtDMI2-MtPUB2 form a prey-predator type negative feedback loop to maintain the nodulation homeostasis [101].

\section{Concluding Remarks and Perspectives}

In recent decades, tremendous progress has been made to understand the roles of PUB E3 ubiquitin ligases in plants. Many PUBs are found in various plant species. PUBs are essential regulators in gene expression by controlling MiRNA biogenesis and involved in various phytohormone signaling pathways. The multifarious functions of PUB E3 ligases can be divided into four categories according to their roles in various biological processes: (1) determination of sexual reproduction; (2) modulating plant growth and development; (3) participation in the signaling of biotic stress and abiotic stress (Figure 1); and (4) most importantly, serving as regulators in the response to various environmental stresses. 


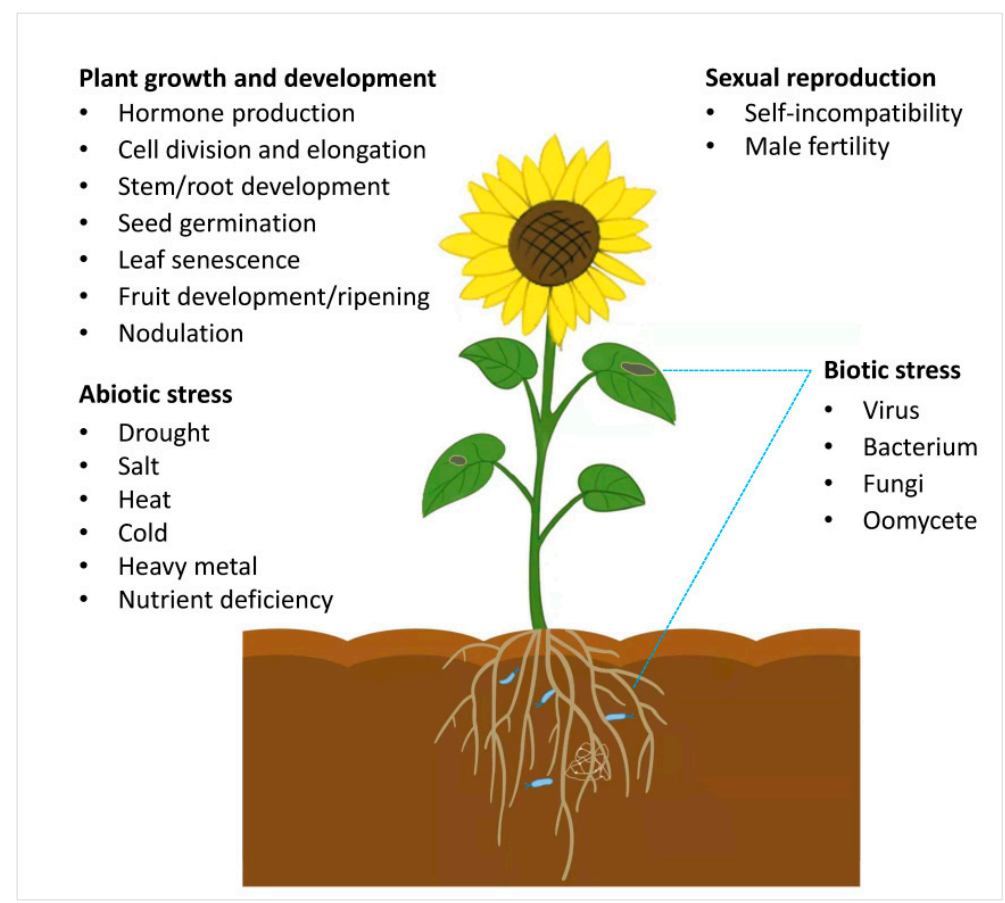

Figure 1. The roles of PUBs in plant growth and development and response to biotic and abiotic stress.

Climate change is associated with increased $\mathrm{CO}_{2}$ concentration and has led to shifts in temperature and rainfall patterns [109], resulting in myriad biotic and abiotic constraints to crop production. Given how crops respond to various environmental stresses, PUBs could represent a gene resource to develop more climate-resilient crops [110]. Nevertheless, it should be pointed out that several PUB members play completely opposite roles in different stresses; for instance, CaPUB1 plays a positive role in cold tolerance, but acts as a negative modulator in salt and drought tolerance [40]. Only very few PUB members play positive roles in response to multiple environmental stresses (Tables 2-4). In addition, there is a lack of comprehensive evaluation of phenotypic effects for most PUBs, especially on agronomic traits, which should be addressed in future studies.

Phylogenetic data show that the PUB gene family has undergone different duplication events in the process of evolution, leading to the emergence of new members, especially in polyploidy plant species. Up to now, only very few PUB members have been structurally characterized. To gain a deeper understanding of PUB's function, more attention should be paid to crystal structural analysis to decipher the interactions with upstream regulators and downstream interactors or substrates.

Additionally, among the identified PUB proteins, some are well characterized. However, most of these studies are preliminary (Tables 2-4). The upstream regulators and downstream substrates, as well as the regulatory networks, are largely unknown. To reveal how many faces PUBs have, research in this area need to be strengthened. A more comprehensive and in-depth study will help us to understand its functional diversity and promote its application in crop genetic improvement.

Author Contributions: X.M., C.Y. and L.L. designed the outline; X.M., C.Y., L.L., M.W., L.Y., Y.Z. (Yining Zhang), Y.Z. (Yanfei Zhang), J.W., C.L. wrote the manuscript; R.J. and M.P.R. revised the manuscript and gave constructive comments. All authors have read and agreed to the published version of the manuscript.

Funding: This work was supported by the National Natural Science Foundation of China (32061143040) and the China Agriculture Research System of MOF and MARA (CARS-03). We apologize for not being able to cite many research papers due to limitations on article length and number of references.

Institutional Review Board Statement: Not applicable. 
Informed Consent Statement: Not applicable.

Data Availability Statement: Not applicable.

Conflicts of Interest: The authors declare no conflict of interest.

$\begin{array}{ll}\text { Abbreviations } \\ \text { AAO } & \text { aldehyde oxidase } \\ \text { ABA } & \text { abscisic acid } \\ \text { BR } & \text { Brassinosteroid } \\ \text { CBF } & \text { C-repeat binding factor } \\ \text { CHIP } & \text { Carboxyl terminus of the HSC70-Interacting Protein } \\ \text { CRL } & \text { cullin-RING ligase } \\ \text { DREB } & \text { dehydration responsive element binding protein } \\ \text { GA } & \text { gibberellic acid } \\ \text { HECT } & \text { Homologous to E6-associatedprotein Carboxyl Terminus } \\ \text { HR } & \text { hypersensitive response } \\ \text { HSP } & \text { heat shock protein } \\ \text { IAA } & \text { indoleacetic acid } \\ \text { ICE } & \text { inducer of CBF expression } \\ \text { JA } & \text { jasmonic acid } \\ \text { NF } & \text { nod factor } \\ \text { PCD } & \text { programmed cell death } \\ \text { PHOR } & \text { photoperiod-responsive } \\ \text { PTI } & \text { PAMP-triggered immunity } \\ \text { PUB } & \text { plant U-box protein } \\ \text { RNAi } & \text { RNA interference } \\ \text { RING } & \text { Really Interesting New Gene } \\ \text { RLK } & \text { Receptor-like kinase } \\ \text { ROS } & \text { Reactive oxygen species } \\ \text { SA } & \text { salicylic acid } \\ \text { SI } & \text { self-incompatibility } \\ \text { SOD } & \text { superoxide dismutase } \\ \text { SRK } & \text { S-domain receptor kinase } \\ \text { TF } & \text { transcription factor } \\ \text { UBC } & \text { ubiquitin-conjugating enzyme } \\ \text { UPS } & \text { ubiquitin 26S-proteasome system } \\ \text { WT } & \text { wild type } \\ & \\ \text { HA }\end{array}$

\section{References}

1. Ciechanover, A.E. The ubiquitin-proteasome pathway: On protein death and cell life. EMBO J. 1998, 17, 7151-7160. [CrossRef] [PubMed]

2. Zeng, L.R.; Park, C.H.; Venu, R.C.; Gough, J.; Wang, G.L. Classification, expression pattern, and E3 ligase activity assay of rice U-box-containing proteins. Mol. Plant 2008, 1, 800-815. [CrossRef] [PubMed]

3. Smalle, J.; Vierstra, R.D. The ubiquitin $26 \mathrm{~S}$ proteasome proteolytic pathway. Annu. Rev. Plant Biol. 2004, 55, 555-590. [CrossRef]

4. Vierstra, R.D. The ubiquitin-26S proteasome system at the nexus of plant biology. Nat. Rev. Mol. Cell Biol. 2009, 10, 385-397. [CrossRef] [PubMed]

5. Koegl, M.; Hoppe, T.; Schlenker, S.; Ulrich, H.D.; Mayer, T.U.; Jentsch, S. A novel ubiquitination factor, E4, is involved in multiubiquitin chain assembly. Cell 1999, 96, 635-644. [CrossRef]

6. Cyr, D.M.; Hohfeld, J.; Patterson, C. Protein quality control: U-box-containing E3 ubiquitin ligases join the fold. Trends Biochem. Sci. 2002, 27, 368-375. [CrossRef]

7. Aravind, L.; Koonin, E.V. The U box is a modified RING finger-a common domain in ubiquitination. Curr. Biol. 2000, 10, R132-R134. [CrossRef]

8. Ohi, M.D.; Vander Kooi, C.W.; Rosenberg, J.A.; Chazin, W.J.; Gould, K.L. Structural insights into the U-box, a domain associated with multi-ubiquitination. Nat. Struct. Biol. 2003, 10, 250-255. [CrossRef]

9. Andersen, P.; Kragelund, B.B.; Olsen, A.N.; Larsen, F.H.; Chua, N.H.; Poulsen, F.M.; Skriver, K. Structure and biochemical function of a prototypical Arabidopsis U-box domain. J. Biol. Chem. 2004, 279, 40053-40061. [CrossRef]

10. Marín, I. Ancient origin of animal U-box ubiquitin ligases. BMC Evol. Biol. 2010, 10, 331. [CrossRef] 
11. Luo, Q.; Li, Y.; Wang, W.; Fei, X.; Deng, X. Genome-wide survey and expression analysis of Chlamydomonas reinhardtii U-box E3 ubiquitin ligases (CrPUBs) reveal a functional lipid metabolism module. PLoS ONE 2015, 10, e0122600. [CrossRef] [PubMed]

12. Wiborg, J.; O'Shea, C.; Skriver, K. Biochemical function of typical and variant Arabidopsis thaliana U-box E3 ubiquitin-protein ligases. Biochem. J. 2008, 413, 447-457. [CrossRef] [PubMed]

13. Ryu, M.Y.; Cho, S.K.; Hong, Y.; Kim, J.; Kim, J.H.; Kim, G.M.; Chen, Y.J.; Knoch, E.; Møller, B.L.; Kim, W.T.; et al. Classification of barley U-box E3 ligases and their expression patterns in response to drought and pathogen stresses. BMC Genom. 2019, $20,326$. [CrossRef] [PubMed]

14. Sharma, B.; Taganna, J. Genome-wide analysis of the U-box E3 ubiquitin ligase enzyme gene family in tomato. Sci. Rep. 2020, 10, 9581. [CrossRef]

15. Kim, D.Y.; Lee, Y.J.; Hong, M.J.; Kim, J.H.; Seo, Y.W. Genome wide analysis of U-box E3 ubiquitin ligases in wheat (Triticum aestivum L.). Int. J. Mol. Sci. 2021, 22, 2699. [CrossRef]

16. Lu, X.; Shu, N.; Wang, D.; Wang, J.; Chen, X.; Zhang, B.; Wang, S.; Guo, L.; Chen, C.; Ye, W. Genome-wide identification and expression analysis of PUB genes in cotton. BMC Genomics 2020, 21, 213. [CrossRef]

17. Wang, N.; Liu, Y.; Cong, Y.; Wang, T.; Zhong, X.; Yang, S.; Li, Y.; Gai, J. Genome-wide identification of soybean U-box E3 ubiquitin ligases and roles of GmPUB8 in negative regulation of drought stress response in Arabidopsis. Plant. Cell Physiol. 2016, 57, 1189-1209. [CrossRef]

18. Chen, L.; Hellmann, H. Plant E3 ligases: Flexible enzymes in a sessile world. Mol. Plant 2013, 6, 1388-1404. [CrossRef]

19. Yang, G.; Ying, G.; Wang, Z.; Pan, W.; Linghu, B.; Pan, Y.; Song, W.; Cui, L.; Nie, X. Genome-wide identification and expression analysis of U-box gene family in wild emmer wheat (Triticum turgidum L. ssp. dicoccoides). Gene 2021, 799, 145840. [CrossRef]

20. Hu, H.; Dong, C.; Sun, D.; Hu, Y.; Xie, J. Genome-wide identification and analysis of U-Box E3 ubiquitin-protein ligase gene family in banana. Int. J. Mol. Sci. 2018, 19, 3874. [CrossRef]

21. Wang, C.; Duan, W.; Riquicho, A.R.; Jing, Z.; Liu, T.; Hou, X.; Li, Y. Genome-wide survey and expression analysis of the PUB family in Chinese cabbage (Brassica rapa ssp. Pekinesis). Mol. Genet. Genomics 2015, 290, 2241-2260. [CrossRef] [PubMed]

22. Tan, B.; Lian, X.; Cheng, J.; Zeng, W.; Zheng, X.; Wang, W.; Ye, X.; Li, J.; Li, Z.; Zhang, L.; et al. Genome-wide identification and transcriptome profiling reveal that E3 ubiquitin ligase genes relevant to ethylene, auxin and abscisic acid are differentially expressed in the fruits of melting flesh and stony hard peach varieties. BMC Genomics 2019, 20, 892. [CrossRef] [PubMed]

23. Wang, C.; Song, B.; Dai, Y.; Zhang, S.; Huang, X. Genome-wide identification and functional analysis of U-box E3 ubiquitin ligases gene family related to drought stress response in Chinese white pear (Pyrus bretschneideri). BMC Plant Biol. 2021, $21,235$. [CrossRef] [PubMed]

24. Monaghan, J.; Xu, F.; Gao, M.; Zhao, Q.; Palma, K.; Long, C.; Chen, S.; Zhang, Y.; Li, X. Two Prp19-like U-box proteins in the MOS4-associated complex play redundant roles in plant innate immunity. PLoS Pathog. 2009, 5, e1000526. [CrossRef]

25. Li, S.; Liu, K.; Zhou, B.; Li, M.; Zhang, S.; Zeng, L.; Zhang, C.; Yu, B. MAC3A and MAC3B, two core subunits of the MOS4associated complex, positively influence miRNA biogenesis. Plant Cell 2018, 30, 481-494. [CrossRef]

26. Zhou, J.; Liu, D.; Wang, P.; Ma, X.; Lin, W.; Chen, S.; Mishev, K.; Lu, D.; Kumar, R.; Vanhoutte, I.; et al. Regulation of Arabidopsis brassinosteroid receptor BRI1 endocytosis and degradation by plant U-box PUB12/PUB13-mediated ubiquitination. Proc. Natl. Acad. Sci. USA 2018, 115, e1906-e1915. [CrossRef]

27. Hu, X.; Qian, Q.; Xu, T.; Zhang, Y.; Dong, G.; Gao, T.; Xie, Q.; Xue, Y. The U-box E3 ubiquitin ligase TUD1 functions with a heterotrimeric $\mathrm{G} \alpha$ subunit to regulate Brassinosteroid-mediated growth in rice. PLoS Genet. 2013, 9, e1003391. [CrossRef]

28. Amador, V.; Monte, E.; Garcia-Martinez, J.L.; Prat, S. Gibberellins signal nuclear import of PHOR1, a photoperiod-responsive protein with homology to Drosophila armadillo. Cell 2001, 106, 343-354. [CrossRef]

29. Monte, E.; Amador, V.; Russo, E.; Martinez-Garcia, J.; Prat, S. PHOR1: A U-box GA signaling component with a role in proteasome degradation? J. Plant Growth Regul. 2003, 22, 152-162. [CrossRef]

30. Jung, C.; Zhao, P.; Seo, J.S.; Mitsuda, N.; Deng, S.; Chua, N.H. PLANT U-BOX PROTEIN10 regulates MYC2 stability in Arabidopsis Plant Cell 2015, 27, 2016-2031. [CrossRef]

31. Samuel, M.A.; Mudgil, Y.; Salt, J.N.; Delmas, F.; Ramachandran, S.; Chilelli, A.; Goring, D.R. Interactions between the S-domain receptor kinases and AtPUB-ARM E3 ubiquitin ligases suggest a conserved signaling pathway in Arabidopsis. Plant Physiol. 2008, 147, 2084-2095. [CrossRef]

32. Chen, X.; Wang, T.; Rehman, A.U.; Wang, Y.; Qi, J.; Li, Z.; Song, C.; Wang, B.; Yang, S.; Gong, Z. Arabidopsis U-box E3 ubiquitin ligase PUB11 negatively regulates drought tolerance by degrading the receptor-like protein kinases LRR1 and KIN7. J. Integr Plant Biol. 2021, 63, 494-509. [CrossRef] [PubMed]

33. Seo, D.H.; Ryu, M.Y.; Jammes, F.; Hwang, J.H.; Turek, M.; Kang, B.G.; Kwak, J.M.; Kim, W.T. Roles of four Arabidopsis U-box E3 ubiquitin ligases in negative regulation of abscisic acid-mediated drought stress responses. Plant Physiol 2012, 160, 556-568. [CrossRef] [PubMed]

34. Cho, S.K.; Ryu, M.Y.; Song, C.; Kwak, J.M.; Kim, W.T. Arabidopsis PUB22 and PUB23 are homologous U-Box E3 ubiquitin ligases that play combinatory roles in response to drought stress. Plant Cell 2008, 20, 1899-1914. [CrossRef] [PubMed]

35. Seo, D.H.; Ahn, M.Y.; Park, K.Y.; Kim, E.Y.; Kim, W.T. The N-terminal UND motif of the Arabidopsis U-box E3 ligase PUB18 is critical for the negative regulation of ABA-mediated stomatal movement and determines its ubiquitination specificity for exocyst subunit Exo70B1. Plant Cell 2016, 28, 2952-2973. [CrossRef] [PubMed] 
36. Ahn, M.Y.; Oh, T.R.; Seo, D.H.; Kim, J.H.; Cho, N.H.; Kim, W.T. Arabidopsis group XIV ubiquitin-conjugating enzymes AtUBC32, AtUBC33, and AtUBC34 play negative roles in drought stress response. J. Plant Physiol. 2018, 230, 73-79. [CrossRef] [PubMed]

37. Seo, D.H.; Lee, A.; Yu, S.G.; Cui, L.H.; Min, H.J.; Lee, S.E.; Cho, N.H.; Kim, S.; Bae, H.; Kim, W.T. OsPUB41, a U-box E3 ubiquitin ligase, acts as a negative regulator of drought stress response in rice (Oryza Sativa L.). Plant Mol. Biol. 2021, 106, $463-477$. [CrossRef]

38. Qin, Q.; Wang, Y.; Huang, L.; Du, F.; Zhao, X.; Li, Z.; Wang, W.; Fu, B. A U-box E3 ubiquitin ligase OsPUB67 is positively involved in drought tolerance in rice. Plant Mol. Biol. 2020, 102, 89-107. [CrossRef]

39. Wang, N.; Liu, Y.; Cai, Y.; Tang, J.; Li, Y.; Gai, J. The soybean U-box gene GmPUB6 regulates drought tolerance in Arabidopsis thaliana. Plant Physiol. Biochem. 2020, 155, 284-296. [CrossRef]

40. Min, H.J.; Jung, Y.J.; Kang, B.G.; Kim, W.T. CaPUB1, a hot pepper U-box E3 ubiquitin ligase, confers enhanced cold stress tolerance and decreased drought stress tolerance in transgenic rice (Oryza sativa L.). Mol. Cells 2016, 39, 250-257.

41. Cho, S.K.; Chung, H.S.; Ryu, M.Y.; Park, M.J.; Lee, M.M.; Bahk, Y.Y.; Kim, J.; Pai, H.S.; Kim, W.T. Heterologous expression and molecular and cellular characterization of CaPUB1 encoding a hot pepper U-Box E3 ubiquitin ligase homolog. Plant Physiol. 2006, 142, 1664-1682. [CrossRef] [PubMed]

42. Zhang, G.; Zhang, M.; Zhao, Z.; Ren, Y.; Li, Q.; Wang, W. Wheat TaPUB1 modulates plant drought stress resistance by improving antioxidant capability. Sci. Rep. 2017, 7, 7549. [CrossRef]

43. Zhang, M.; Zhang, G.Q.; Kang, H.H.; Zhou, S.M.; Wang, W. TaPUB1, a putative E3 ligase gene from wheat, enhances salt stress tolerance in transgenic Nicotiana benthamiana. Plant Cell Physiol. 2017, 58, 1673-1688. [CrossRef] [PubMed]

44. Wang, W.; Wang, W.; Wu, Y.; Li, Q.; Zhang, G.; Shi, R.; Yang, J.; Wang, Y.; Wang, W. The involvement of wheat U-box E3 ubiquitin ligase TaPUB1 in salt stress tolerance. J. Integr. Plant Biol. 2020, 62, 631-651. [CrossRef] [PubMed]

45. Zhang, G.; Yang, J.; Zhang, M.; Li, Q.; Wu, Y.; Zhao, X.; Zhang, H.; Wang, Y.; Wu, J.; Wang, W. Wheat TaPUB1 regulates Cd uptake and tolerance by promoting the degradation of TaIRT1 and TaIAA17. J. Agric. Food Chem. 2021, 69, 5818-5829. [CrossRef] [PubMed]

46. Tong, S.; Chen, N.; Wang, D.; Ai, F.; Liu, B.; Ren, L.; Chen, Y.; Zhang, J.; Lou, S.; Liu, H.; et al. The U-box E3 ubiquitin ligase PalPUB79 positively regulates ABA-dependent drought tolerance via ubiquitination of PalWRKY77 in Populus. Plant Biotechnol. J. 2021, 19, 2561-2575. [CrossRef] [PubMed]

47. Wang, J.; Liu, S.; Liu, H.; Chen, K.; Zhang, P. PnSAG1, an E3 ubiquitin ligase of the Antarctic moss Pohlia nutans, enhanced sensitivity to salt stress and ABA. Plant Physiol. Biochem. 2019, 141, 343-352. [CrossRef] [PubMed]

48. Zhang, M.; Zhao, J.; Li, L.; Gao, Y.; Zhao, L.; Patil, S.B.; Fang, J.; Zhang, W.; Yang, Y.; Li, M.; et al. The Arabidopsis U-box E3 ubiquitin ligase PUB30 negatively regulates salt tolerance by facilitating BRI1 kinase inhibitor 1 (BKI1) degradation. Plant Cell Environ. 2017, 40, 2831-2843. [CrossRef]

49. Li, Q.; Li, B.; Wang, J.; Chang, X.; Mao, X.; Jing, R. TaPUB15, a U-Box E3 ubiquitin ligase gene from wheat, enhances salt tolerance in rice. Food Energy Secur. 2021, 10, e250. [CrossRef]

50. Wu, Y.; Wang, W.; Li, Q.; Zhang, G.; Zhao, X.; Li, G.; Li, Y.; Wang, Y.; Wang, W. The wheat E3 ligase TaPUB26 is a negative regulator in response to salt stress in transgenic Brachypodium distachyon. Plant Sci. 2020, 294, 110441. [CrossRef]

51. Peng, L.; Wan, X.; Huang, K.; Pei, L.; Xiong, J.; Li, X.; Wang, J. AtPUB48 E3 ligase plays a crucial role in the thermotolerance of Arabidopsis. Biochem. Biophys. Res. Commun. 2019, 509, 281-286. [CrossRef] [PubMed]

52. Zhang, Y.; Xia, G.; Zhu, Q. Conserved and unique roles of chaperone-dependent E3 ubiquitin ligase CHIP in plants. Front. Plant Sci. 2021, 12, 699756. [CrossRef] [PubMed]

53. Wang, X.; Ding, Y.; Li, Z.; Shi, Y.; Wang, J.; Hua, J.; Gong, Z.; Zhou, J.M.; Yang, S. PUB25 and PUB26 promote plant Freezing tolerance by degrading the cold signaling negative regulator MYB15. Dev. Cell 2019, 51, 222-235.e5. [CrossRef] [PubMed]

54. Chinnusamy, V.; Ohta, M.; Kanrar, S.; Lee, B.H.; Hong, X.; Agarwal, M.; Zhu, J.K. ICE1: A regulator of cold-induced transcriptome and freezing tolerance in Arabidopsis. Genes Dev. 2003, 17, 1043-1054. [CrossRef] [PubMed]

55. Yao, W.; Wang, L.; Wang, J.; Ma, F.; Yang, Y.; Wang, C.; Tong, W.; Zhang, J.; Xu, Y.; Wang, X.; et al. VpPUB24, a novel gene from Chinese grapevine, Vitis pseudoreticulata, targets VpICE1 to enhance cold tolerance. J. Exp. Bot. 2017, 68, 2933-2949. [CrossRef] [PubMed]

56. Ismail, A.M.; Horie, T. Genomics, physiology, and molecular breeding approaches for improving salt tolerance. Annu. Rev. Plant Biol. 2017, 68, 405-434. [CrossRef]

57. Hwang, J.H.; Seo, D.H.; Kang, B.G.; Kwak, J.M.; Kim, W.T. Suppression of Arabidopsis AtPUB30 resulted in increased tolerance to salt stress during germination. Plant Cell Rep. 2015, 34, 277-289. [CrossRef]

58. Zhang, Y.; Lai, X.; Yang, S.; Ren, H.; Yuan, J.; Jin, H.; Shi, C.; Lai, Z.; Xia, G. Functional analysis of tomato CHIP ubiquitin E3 ligase in heat tolerance. Sci. Rep. 2021, 11, 1713. [CrossRef]

59. Dhup, S.; Dhawan, V. Effect of nitrogen concentration on lipid productivity and fatty acid composition of Monoraphidium sp. Bioresour. Technol. 2014, 152, 572-575. [CrossRef]

60. Lu, D.; Lin, W.; Gao, X.; Wu, S.; Cheng, C.; Avila, J.; Heese, A.; Devarenne, T.P.; He, P.; Shan, L. Direct ubiquitination of pattern recognition receptor FLS2 attenuates plant innate immunity. Science 2011, 332, 1439-1442. [CrossRef]

61. Li, W.; Ahn, I.P.; Ning, Y.; Park, C.H.; Zeng, L.; Whitehill, J.G.; Lu, H.; Zhao, Q.; Ding, B.; Xie, Q.; et al. The U-Box/ARM E3 ligase PUB13 regulates cell death, defense, and flowering time in Arabidopsis. Plant Physiol. 2012, 159, 239-250. [CrossRef] [PubMed] 
62. Li, W.; Dai, L.; Wang, G.L. PUB13, a U-box/ARM E3 ligase, regulates plant defense, cell death, and flowering time. Plant Signal. Behav. 2012, 7, 898-900. [CrossRef] [PubMed]

63. Ma, A.; Zhang, D.; Wang, G.; Wang, K.; Li, Z.; Gao, Y.; Li, H.; Bian, C.; Cheng, J.; Han, Y.; et al. Verticillium dahliae effector VDAL protects MYB6 from degradation by interacting with PUB25 and PUB26 E3 ligases to enhance Verticillium wilt resistance. Plant Cell 2021, 33, 3675-3699. [CrossRef] [PubMed]

64. Liu, J.; Park, C.H.; He, F.; Nagano, M.; Wang, M.; Bellizzi, M.; Zhang, K.; Zeng, X.; Liu, W.; Ning, Y.; et al. The RhoGAP SPIN6 associates with SPL11 and OsRac1 and negatively regulates programmed cell death and innate immunity in rice. PLoS Pathog. 2015, 11, e1004629. [CrossRef]

65. Liu, J.; Li, W.; Ning, Y.; Shirsekar, G.; Cai, Y.; Wang, X.; Dai, L.; Wang, Z.; Liu, W.; Wang, G.L. The U-Box E3 ligase SPL11/PUB13 is a convergence point of defense and flowering signaling in plants. Plant Physiol. 2012, 160, 28-37. [CrossRef]

66. Wang, J.; Qu, B.; Dou, S.; Li, L.; Yin, D.; Pang, Z.; Zhou, Z.; Tian, M.; Liu, G.; Xie, Q.; et al. The E3 ligase OsPUB15 interacts with the receptor-like kinase PID2 and regulates plant cell death and innate immunity. BMC Plant Biol. 2015, 15, 49. [CrossRef]

67. Ishikawa, K.; Yamaguchi, K.; Sakamoto, K.; Yoshimura, S.; Inoue, K.; Tsuge, S.; Kojima, C.; Kawasaki, T. Bacterial effector modulation of host E3 ligase activity suppresses PAMP-triggered immunity in rice. Nat. Commun. 2014, 5, 5430. [CrossRef]

68. Zhang, C.; Wei, Y.; Xu, L.; Wu, K.C.; Yang, L.; Shi, C.N.; Yang, G.Y.; Chen, D.; Yu, F.F.; Xie, Q.; et al. A Bunyavirus-inducible ubiquitin ligase targets RNA polymerase IV for degradation during viral pathogenesis in rice. Mol. Plant 2020, 13, 836-850. [CrossRef]

69. He, Q.; McLellan, H.; Boevink, P.C.; Sadanandom, A.; Xie, C.; Birch, P.R.; Tian, Z. U-box E3 ubiquitin ligase PUB17 acts in the nucleus to promote specific immune pathways triggered by Phytophthora infestans. J. Exp. Bot. 2015, 66, 3189-3199. [CrossRef]

70. Qin, T.; Liu, S.; Zhang, Z.; Sun, L.; He, X.; Lindsey, K.; Zhu, L.; Zhang, X. GhCyP3 improves the resistance of cotton to Verticillium dahliae by inhibiting the E3 ubiquitin ligase activity of GhPUB17. Plant Mol. Biol. 2019, 99, 379-393. [CrossRef]

71. Han, P.L.; Dong, Y.H.; Gu, K.D.; Yu, J.Q.; Hu, D.G.; Hao, Y.J. The apple U-box E3 ubiquitin ligase MdPUB29 contributes to activate plant immune response to the fungal pathogen Botryosphaeria dothidea. Planta 2019, 249, 1177-1188. [CrossRef] [PubMed]

72. Li, S.; Hanlon, R.; Wise, H.; Pal, N.; Brar, H.; Liao, C.; Gao, H.; Perez, E.; Zhou, L.; Tyler, B.M.; et al. Interaction of Phytophthora sojae effector Avr1b with E3 ubiquitin ligase GmPUB1 is required for recognition by soybeans carrying Phytophthora resistance Rps1-b and Rps1-k genes. Front. Plant Sci. 2021, 12, 725571. [CrossRef] [PubMed]

73. Lin, Y.; Hu, Q.; Zhou, J.; Yin, W.; Yao, D.; Shao, Y.; Zhao, Y.; Guo, B.; Xia, Y.; Chen, Q.; et al. Phytophthora sojae effector Avr1d functions as an E2 competitor and inhibits ubiquitination activity of GmPUB13 to facilitate infection. Proc. Natl. Acad. Sci. USA 2021, 118, e2018312118. [CrossRef] [PubMed]

74. Yin, Z.; Chen, J.; Zeng, L.; Goh, M.; Leung, H.; Khush, G.S.; Wang, G.L. Characterizing rice lesion mimic mutants and identifying a mutant with broad-spectrum resistance to rice blast and bacterial blight. Mol. Plant Microbe Interact. 2000, 13, 869-876. [CrossRef] [PubMed]

75. Yang, C.W.; González-Lamothe, R.; Ewan, R.A.; Rowland, O.; Yoshioka, H.; Shenton, M.; Ye, H.; O’Donnell, E.; Jones, J.D.; Sadanandom, A. The E3 ubiquitin ligase activity of Arabidopsis PLANT U-BOX17 and its functional tobacco homolog ACRE276 are required for cell death and defense. Plant Cell 2006, 18, 1084-1098. [CrossRef]

76. Pintard, L.; Willems, A.; Peter, M. Cullin-based ubiquitin ligases: Cul3-BTB complexes join the family. EMBO J. 2004, 23, 1681-1687. [CrossRef]

77. Orosa, B.; He, Q.; Mesmar, J.; Gilroy, E.M.; McLellan, H.; Yang, C.; Craig, A.; Bailey, M.; Zhang, C.; Moore, J.D.; et al. BTB-BACK domain protein POB1 suppresses immune cell death by targeting ubiquitin E3 ligase PUB17 for degradation. PLoS Genet. 2017, 13, e1006540. [CrossRef]

78. Han, P.; Wang, C.; Liu, X.; Dong, Y.; Jiang, H.; Hu, D.; Hao, Y. BTB-BACK domain E3 ligase MdPOB1 Suppresses plant pathogen defense against Botryosphaeria dothidea by ubiquitinating and degrading MdPUB29 protein in apple. Plant Cell Physiol. 2019, 60, 2129-2140. [CrossRef]

79. González-Lamothe, R.; Tsitsigiannis, D.I.; Ludwig, A.A.; Panicot, M.; Shirasu, K.; Jones, J.D. The U-box protein CMPG1 is required for efficient activation of defense mechanisms triggered by multiple resistance genes in tobacco and tomato. Plant Cell 2006, 18, 1067-1083. [CrossRef]

80. Bos, J.I.; Armstrong, M.R.; Gilroy, E.M.; Boevink, P.C.; Hein, I.; Taylor, R.M.; Zhendong, T.; Engelhardt, S.; Vetukuri, R.R.; Harrower, B.; et al. Phytophthora infestans effector AVR3a is essential for virulence and manipulates plant immunity by stabilizing host E3 ligase CMPG1. Proc. Natl. Acad. Sci. USA 2010, 107, 9909-9914. [CrossRef]

81. Gilroy, E.M.; Taylor, R.M.; Hein, I.; Boevink, P.; Sadanandom, A.; Birch, P.R. CMPG1-dependent cell death follows perception of diverse pathogen elicitors at the host plasma membrane and is suppressed by Phytophthora infestans RXLR effector AVR3a. New Phytol. 2011, 190, 653-666. [CrossRef] [PubMed]

82. Saini, S.; Sharma, I.; Kaur, N.; Pati, P.K. Auxin: A master regulator in plant root development. Plant Cell Rep. 2013, 32, 741-757. [CrossRef] [PubMed]

83. Riedelsberger, J.; Blatt, M.R. Roots -the hidden provider. Front. Plant Sci. 2017, 8, 1021. [CrossRef] [PubMed]

84. Kinoshita, A.; Seo, M.; Kamiya, Y.; Sawa, S. Mystery in genetics: PUB4 gives a clue to the complex mechanism of CLV signaling pathway in the shoot apical meristem. Plant Signal. Behav. 2015, 10, e1028707. [CrossRef] 
85. Kinoshita, A.; ten Hove, C.A.; Tabata, R.; Yamada, M.; Shimizu, N.; Ishida, T.; Yamaguchi, K.; Shigenobu, S.; Takebayashi, Y.; Iuchi, S.; et al. A plant U-box protein, PUB4, regulates asymmetric cell division and cell proliferation in the root meristem. Development 2015, 142, 444-453. [CrossRef]

86. Sankaranarayanan, S.; Samuel, M.A. A proposed role for selective autophagy in regulating auxin-dependent lateral root development under phosphate starvation in Arabidopsis. Plant Signal. Behav. 2015, 10, e989749. [CrossRef]

87. Park, J.J.; Yi, J.; Yoon, J.; Cho, L.H.; Ping, J.; Jeong, H.J.; Cho, S.K.; Kim, W.T.; An, G. OsPUB15, an E3 ubiquitin ligase, functions to reduce cellular oxidative stress during seedling establishment. Plant J. 2011, 65, 194-205. [CrossRef]

88. Raab, S.; Drechsel, G.; Zarepour, M.; Hartung, W.; Koshiba, T.; Bittner, F.; Hoth, S. Identification of a novel E3 ubiquitin ligase that is required for suppression of premature senescence in Arabidopsis. Plant J. 2009, 59, 39-51. [CrossRef]

89. Zhang, Z.; Xu, M.; Guo, Y. Ring/U-box Protein AtUSR1 functions in promoting leaf senescence through JA signaling pathway in Arabidopsis. Front. Plant Sci. 2020, 11, 608589. [CrossRef]

90. Cai, Y.; Vega-Sánchez, M.E.; Park, C.H.; Bellizzi, M.; Guo, Z.; Wang, G.L. RBS1, an RNA binding protein, interacts with SPIN1 and is involved in flowering time control in rice. PLoS ONE 2014, 9, e87258. [CrossRef]

91. Hu, D.G.; Yu, J.Q.; Han, P.L.; Xie, X.B.; Sun, C.H.; Zhang, Q.Y.; Wang, J.H.; Hao, Y.J. The regulatory module MdPUB29-MdbHLH3 connects ethylene biosynthesis with fruit quality in apple. New Phytol. 2019, 221, 1966-1982. [CrossRef] [PubMed]

92. Yu, Y.; Meng, X.; Guo, D.; Yang, S.; Zhang, G.; Liang, Z. Grapevine U-box E3 ubiquitin ligase VlPUB38 negatively regulates fruit ripening by facilitating abscisic-aldehyde oxidase degradation. Plant Cell Physiol. 2021, 61, 2043-2054. [CrossRef] [PubMed]

93. Wang, H.; Lu, Y.; Jiang, T.; Berg, H.; Li, C.; Xia, Y. The Arabidopsis U-box/ARM repeat E3 ligase AtPUB4 influences growth and degeneration of tapetal cells, and its mutation leads to conditional male sterility. Plant J. 2013, 74, 511-523. [CrossRef] [PubMed]

94. Wang, Y.; Wu, Y.; Yu, B.; Yin, Z.; Xia, Y. EXTRA-LARGE G PROTEINs interact with E3 ligases PUB4 and PUB2 and function in cytokinin and developmental processes. Plant Physiol. 2017, 173, 1235-1246. [CrossRef] [PubMed]

95. Chen, L.; Deng, R.; Liu, G.; Jin, J.; Wu, J.; Liu, X. Cytological and transcriptome analyses reveal OsPUB73 defect affects the gene expression associated with tapetum or pollen exine abnormality in rice. BMC Plant Biol. 2019, 19, 546. [CrossRef] [PubMed]

96. Indriolo, E.; Goring, D.R. A conserved role for the ARC1 E3 ligase in Brassicaceae self-incompatibility. Front. Plant Sci. 2014, 5, 181. [CrossRef]

97. Stone, S.L.; Anderson, E.M.; Mullen, R.T.; Goring, D.R. ARC1 is an E3 ubiquitin ligase and promotes the ubiquitination of proteins during the rejection of self-incompatible Brassica pollen. Plant Cell 2003, 15, 885-898. [CrossRef]

98. Wang, N.; Xing, Y.; Lou, Q.; Feng, P.; Liu, S.; Zhu, M.; Yin, W.; Fang, S.; Lin, Y.; Zhang, T.; et al. Dwarf and short grain 1, encoding a putative U-box protein regulates cell division and elongation in rice. J. Plant Physiol. 2017, 209, 84-94. [CrossRef]

99. Kiss, E.; Oláh, B.; Kaló, P.; Morales, M.; Heckmann, A.B.; Borbola, A.; Lózsa, A.; Kontár, K.; Middleton, P.; Downie, J.A.; et al. LIN, a novel type of U-box/WD40 protein, controls early infection by rhizobia in legumes. Plant Physiol. 2009, 151, 1239-1249. [CrossRef]

100. Mbengue, M.; Camut, S.; de Carvalho-Niebel, F.; Deslandes, L.; Froidure, S.; Klaus-Heisen, D.; Moreau, S.; Rivas, S.; Timmers, T.; Hervé, C.; et al. The Medicago truncatula E3 ubiquitin ligase PUB1 interacts with the LYK3 symbiotic receptor and negatively regulates infection and nodulation. Plant Cell 2010, 22, 3474-3488. [CrossRef]

101. Liu, J.; Deng, J.; Zhu, F.; Li, Y.; Lu, Z.; Qin, P.; Wang, T.; Dong, J. The MtDMI2-MtPUB2 negative feedback loop plays a role in nodulation homeostasis. Plant Physiol. 2018, 176, 3003-3026. [CrossRef] [PubMed]

102. Melhorn, V.; Matsumi, K.; Koiwai, H.; Ikegami, K.; Okamoto, M.; Nambara, E.; Bittner, F.; Koshiba, T. Transient expression of AtNCED3 and AAO3 genes in guard cells causes stomatal closure in Vicia faba. J. Plant Res. 2008, 121, 125-131. [CrossRef] [PubMed]

103. Vogelmann, K.; Drechsel, G.; Bergler, J.; Subert, C.; Philippar, K.; Soll, J.; Engelmann, J.C.; Engelsdorf, T.; Voll, L.M.; Hoth, S. Early senescence and cell death in Arabidopsis saul1 mutants involves the PAD4-dependent salicylic acid pathway. Plant Physiol. 2012, 159, 1477-1487. [CrossRef] [PubMed]

104. Zhou, J.; Lu, D.; Xu, G.; Finlayson, S.A.; He, P.; Shan, L. The dominant negative ARM domain uncovers multiple functions of PUB13 in Arabidopsis immunity, flowering, and senescence. J. Exp. Bot. 2015, 66, 3353-3366. [CrossRef]

105. Klee, H.J.; Giovannoni, J.J. Genetics and control of tomato fruit ripening and quality attributes. Annu. Rev. Genet. 2011, 45, 41-59. [CrossRef]

106. Takayama, S.; Isogai, A. Self-incompatibility in plants. Annu. Rev. Plant Biol. 2005, 56, 467-489. [CrossRef]

107. Indriolo, E.; Tharmapalan, P.; Wright, S.I.; Goring, D.R. The ARC1 E3 ligase gene is frequently deleted in self-compatible Brassicaceae species and has a conserved role in Arabidopsis lyrata self-pollen rejection. Plant Cell 2012, 24, 4607-4620. [CrossRef]

108. Hervé, C.; Lefebvre, B.; Cullimore, J. How many E3 ubiquitin ligase are involved in the regulation of nodulation? Plant Signal. Behav. 2011, 6, 660-664. [CrossRef]

109. Trebicki, P. Climate change and plant virus epidemiology. Virus Res. 2020, 286, 198059. [CrossRef]

110. Bailey-Serres, J.; Parker, J.E.; Ainsworth, E.A.; Oldroyd, G.E.D.; Schroeder, J.I. Genetic strategies for improving crop yields. Nature 2019, 575, 109-118. [CrossRef] 